\title{
Modeling the South American regional smoke plume: aerosol optical depth variability and surface shortwave flux perturbation
}

\author{
N. E. Rosário ${ }^{1,2, *}$, K. M. Longo ${ }^{1}$, S. R. Freitas ${ }^{1}$, M. A. Yamasoe $^{2}$, and R. M. Fonseca ${ }^{1}$ \\ ${ }^{1}$ National Institute for Space Research, São José dos Campos, Brazil \\ ${ }^{2}$ Atmospheric Sciences Department, University of São Paulo, São Paulo, Brazil \\ * now at: Environment Sciences Division, Federal University of São Paulo, Diadema, Brazil
}

Correspondence to: N. E. Rosário (nilton.rosario@inpe.br)

Received: 5 June 2012 - Published in Atmos. Chem. Phys. Discuss.: 17 July 2012

Revised: 22 February 2013 - Accepted: 22 February 2013 - Published: 15 March 2013

\begin{abstract}
Intra-seasonal variability of smoke aerosol optical depth (AOD) and downwelling solar irradiance at the surface during the 2002 biomass burning season in South America was modeled using the Coupled Chemistry-Aerosol-Tracers Transport model with the Brazilian developments on the Regional Atmospheric Modeling System (CCATT-BRAMS). Measurements of total and fine mode fraction (FMF) AOD from the AErosol RObotic NETwork (AERONET) and solar irradiance at the surface from the Solar Radiation Network (SolRad-NET) were used to evaluate model results. In general, the major features associated with AOD evolution over the southern part of the Amazon basin and cerrado ecosystem are captured by the model. The main discrepancies were found for high aerosol loading events. In the northeastern portion of the Amazon basin the model systematically underestimated total AOD, as expected, since smoke contribution is not dominant as it is in the southern portion and emissions other than smoke were not considered in the simulation. Better agreement was obtained comparing the model results with observed FMF AOD, which pointed out the relevance of coarse mode aerosol emission in that region. Likewise, major discrepancies over cerrado during high AOD events were found to be associated with coarse mode aerosol omission in our model. The issue of high aerosol loading events in the southern part of the Amazon was related to difficulties in predicting the smoke AOD field, which was discussed in the context of emissions shortcomings. The Cuiabá cerrado site was the only one where the highest quality AERONET data were unavailable for both total and FMF AOD. Thus, lower quality data were used. Root-meansquare error (RMSE) between the model and observed FMF
\end{abstract}

AOD decreased from 0.34 to 0.19 when extreme AOD events (FMF AOD $_{550 \mathrm{~nm}} \geq 1.0$ ) and Cuiabá were excluded from the analysis. Downward surface solar irradiance comparisons also followed similar trends when extreme AOD were excluded. This highlights the need to improve modelling of the regional smoke plume in order to enhance the accuracy of the radiative energy budget. An aerosol optical model based on the mean intensive properties of smoke from the southern part of the Amazon basin produced a radiative flux perturbation efficiency (RFPE) of $-158 \mathrm{Wm}^{-2} / \mathrm{AOD}_{550 \mathrm{~nm}}$ at noon. This value falls between $-154 \mathrm{Wm}^{-2} / \mathrm{AOD}_{550 \mathrm{~nm}}$ and $-187 \mathrm{Wm}^{-2} / \mathrm{AOD}_{550 \mathrm{~nm}}$, the range obtained when spatially varying optical models were considered. The $24 \mathrm{~h}$ average surface radiative flux perturbation over the biomass burning season varied from $-55 \mathrm{Wm}^{-2}$ close to smoke sources in the southern part of the Amazon basin and cerrado to $-10 \mathrm{Wm}^{-2}$ in remote regions of the southeast Brazilian coast.

\section{Introduction}

The aerosol direct radiative effect (DRE), which consists of scattering and absorption of solar radiation, plays an important role in Earth's radiative energy budget (Haywood and Boucher, 2000; Menon, 2004; Ramanathan et al., 2001). Despite the advances achieved during recent decades regarding the role of aerosols in Earth's climate processes, the modeling of aerosol DRE in climate models is still a challenging task (Schulz et al., 2006, Forster et al., 2007). Estimates of the aerosol global annual mean Direct Radiative Forcing (DRF) diverge considerably among climate models, 
ranging from +0.04 to $-0.41 \mathrm{Wm}^{-2}$ (Schulz et al., 2009). The relationship between aerosol optical properties and radiative forcing efficiency, forcing per unit of optical depth, has been pointed out as a key aspect concerning model diversity (Schulz et al., 2006, 2009), particularly for regions dominated by carbonaceous and dust aerosols (Kinne et al., 2006). Over South America in particular, while some models simulated spatial variability in DRF from +2 to $-2 \mathrm{Wm}^{-2}$, others exhibited lower geographical variation (from -0.2 to $-0.4 \mathrm{Wm}^{-2}$ ). Biomass burning is a major source of carbonaceous aerosols to the regional atmosphere, yet characterization of observations and model representation of smoke aerosol emissions and spatial and temporal variability of abundance and intrinsic optical properties are still uncertain (Kinne et al., 2006; Reid et al., 2005; Longo et al., 2010). Kinne et al. (2006) found the biomass burning season in South America to start and peak too early in models used by the Aerosol interComparison project (AeroCom, Textor et al., 2007) when compared with ground-based and satellite observations. The study also pointed out that models in general underestimate the strength of the biomass burning season.

The present paper describes results of a modeling effort aiming to simulate the South American regional smoke plume produced during the 2002 biomass burning season. The study was conducted using the Chemistry-Coupled Aerosol and Tracers Transport model with the Brazilian developments on the Regional Atmospheric Modeling System (CCATT-BRAMS, Freitas et al., 2009; Longo et al., 2010, 2013) developed at the Brazilian National Institute for Space Research for regional studies of air quality impact on public health, weather forecasting and climate processes. The presented results focus on the simulation of the AOD of the regional smoke plume and the associated radiative flux perturbation (RFP) of the solar radiation at the surface. Downward solar radiation at the surface is a fundamental component in the diurnal cycle of the energy budget. The ability of the model to correctly simulate the AOD field is crucial to an accurate modeling of the solar radiation field. To evaluate the CCATT-BRAMS results, collocated observations of AOD from the AERosol RObotic NETwork (AERONET, Holben et al., 1998) sun photometers and downwelling solar irradiance at the surface from Solar Radiation Network (SolRadNET, Schafer et al., 2002) pyranometers are used. The paper is divided as follows: Sect. 2 presents a description of the CCATT-BRAMS system with a particular focus on the emission sources prescription and optical-radiative module. Section 3 describes the experimental data and methods. Results and discussion are presented in Sect. 4. The first results that are presented and discussed are comparisons between model-calculated and observed seasonal variability of aerosol optical depth, followed by an evaluation of modeled downwelling solar fluxes at the surface. Next, we discuss RFP efficiencies (RFPE) as parameterized in CCATTBRAMS based on optical properties models derived from
AERONET data. An estimate of RFPE from an independent empirical approach based on pyranometer measurements and a radiative transfer closure experiment is also presented. Finally, we evaluate the surface RFP induced by the regional smoke plume on a $24 \mathrm{~h}$ basis and at specific times of day. Aiming at consistent terminology, radiative flux perturbation (RFP) was adopted to denominate the impact of aerosol direct radiative effect instead of radiative forcing (RF) following Lohmann et al. (2010) suggestion. Conclusions are presented in Sect. 5 .

\section{Modeling system description}

CCATT-BRAMS consists of a numerical system designed to predict and study emission, deposition and transport of aerosols and other tracers at a regional scale. CCATT is an on-line Eulerian transport model and BRAMS is an atmospheric circulation model based on the Regional Atmospheric Modelling System (RAMS, Walko et al., 2000) with specific developments and parameterizations for South American tropical regions (Freitas et al., 2009). CCATTBRAMS is fully coupled in order to solve the transport of gaseous compounds and aerosol particles simultaneously with the atmospheric state evolution using exactly the same timestep as well as dynamics and physical parameterizations. The model includes gaseous chemistry, photochemistry, scavenging and dry deposition. The resultant 3-D aerosol loading is used as an input to the optical-radiative transfer module in order to simulate the aerosol direct and semi-direct radiative effects. Therefore, aerosol impacts on the energy budget and atmospheric thermodynamics are considered (Freitas et al., 2009; Longo et al., 2006). The modeling of smoke aerosol particles is the focus of the present study, therefore only biomass burning emission sources were considered.

\subsection{Emission}

Smoke emissions were prescribed using the Brazilian Biomass Burning Emission Model (3BEM, Freitas et al., 2005; Longo et al., 2010). The 3BEM smoke particles emissions are based on a database of fire pixel counts and burned area derived from the combination of remote-sensing fire products from Geostationary Operational Environmental Satellite-Wildfire Automated Biomass Burning Algorithm (GOES WF ABBA product; Prins et al., 1998), the Brazilian National Institute for Space Research (INPE) fire product, which is based on the Advanced Very High Resolution Radiometer (AVHRR) aboard the NOAA polar orbiting satellites series (Setzer and Pereira, 1991), and the Moderate Resolution Imaging Spectroradiometer (MODIS) fire product (Giglio et al., 2003). The three fire product databases are combined using a filter algorithm to avoid double counting of the same fire, by eliminating additional fires within 


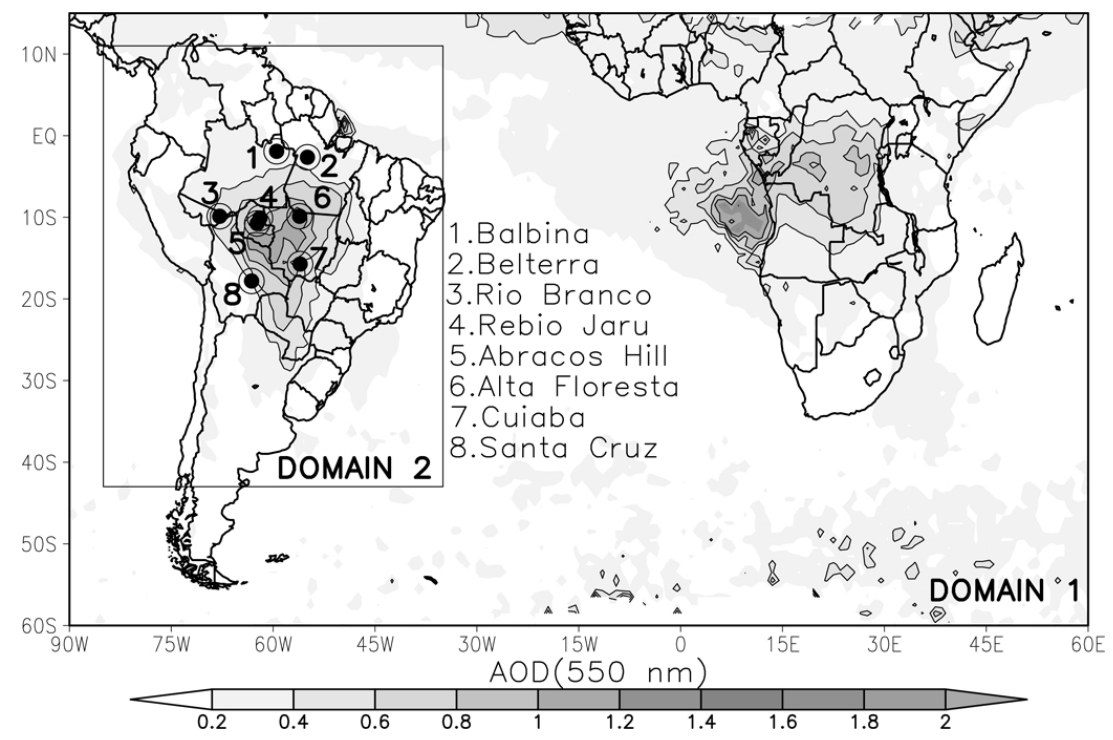

Fig. 1. Geographic locations of analyzed experimental sites depicted along the mean field of aerosol optical depth (AOD) at $550 \mathrm{~nm}$ during the 2002 biomass burning season in South America obtained from MODIS aboard the TERRA satellite.

a circle with a radius of $1 \mathrm{~km}$. For detected fire pixels, the emitted mass is obtained combining the amount of available above-ground biomass and combustion and emission factors for specific species in accordance with vegetation type. The fire detection maps are merged with $1 \mathrm{~km}$ resolution land use data (Belward, 1996; Sestini et al., 2003) to provide the associated emission and combustion factors through a look-up table. The emission and combustion factors for each biome, which include tropical forest, cerrado and pasture, are based on Andreae and Merlet (2001) and Longo et al. (2009). The total emitted mass of aerosol particles per grid box is calculated by adding the individual mass over all fires in that grid box. The emission units are $\mathrm{kg} \mathrm{m}^{-2} \mathrm{day}^{-1}$. The diurnal cycle for the biomass burning emissions is prescribed using a Gaussian function centered at 18:00 UTC (Freitas et al., 2011), which is based on the typical diurnal cycle of fire occurrence over South America (Prins et al., 1998). A detailed description of the 3BEM model is presented in Longo et al. (2010) and Freitas et al. (2011). For the present study, only emissions of carbon monoxide (CO) and smoke fine mode particles, i.e. particles with a diameter smaller than $2.5 \mu \mathrm{m}\left(\mathrm{PM}_{2.5}\right)$, were considered. In areas heavily affected by biomass burning, in the southern region of the Amazon basin and the cerrado ecosystem, fine mode aerosols contribute, on average, to $90 \%$ and $85 \%$, respectively, of the total aerosol optical depth in the visible spectrum (Rosário, 2011). Moreover, fine mode particles dominate the intensive radiative properties of the regional smoke plume (Reid et al., 2005). Although only smoke emissions were considered in the present study, it is worth mentioning that the CCATTBRAMS system is able to treat distinct aerosol types.

\subsection{Model configuration}

CCATT-BRAMS was configured and run with two domains (Fig. 1). The first consisted of a larger domain with $140 \mathrm{~km}$ horizontal resolution covering South America and Africa aiming to capture inflow of smoke from Africa and transport of South American smoke to remote areas of the southwestern portion of the Atlantic Ocean. The second, a nested grid, consisted of a smaller domain covering only South America and with a horizontal resolution of $35 \mathrm{~km}$. For both domains, 42 vertical levels were included, with vertical resolution varying from $150 \mathrm{~m}$ in the lower troposphere to a maximum of $850 \mathrm{~m}$ in the upper troposphere. Atmospheric initial and boundary conditions were assimilated from the 6 hourly analysis of the global circulation model CPTEC T126 (100 km in the horizontal resolution) from the Brazilian Center for Weather Forecasting and Climate Studies (Cavalcanti et al., 2002) using the RAMS 4DDA (four-dimensional data assimilation) assimilation technique.

\subsection{Optical-radiative module}

The CCATT-BRAMS optical-radiative module is based on a modified version of the Community Aerosol and Radiation Model for Atmosphere (CARMA, Toon et al., 1989; Colarco et al., 2002). The original CARMA version simultaneously considered an aerosol microphysics scheme and a twostream radiative transfer module for both solar and terrestrial spectral regions. Major standard microphysical processes, such as coagulation, condensational growth and particle sedimentation, were included. Aerosol size distributions were prescribed using several bins and including different chemical elements. Aerosol particles were treated as spherical and 
(a)

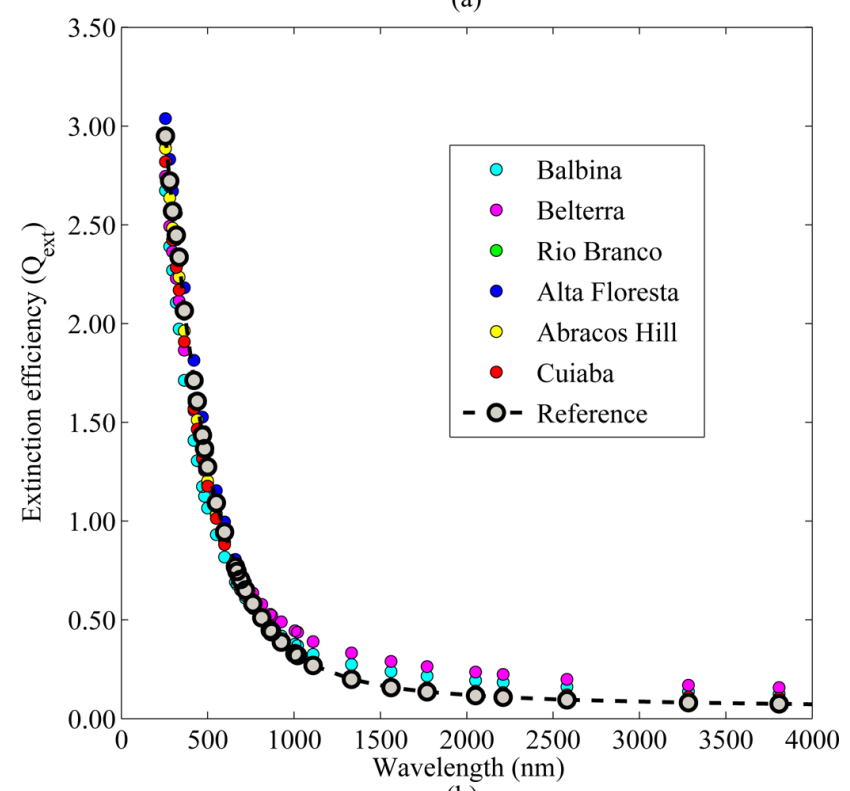

(b)

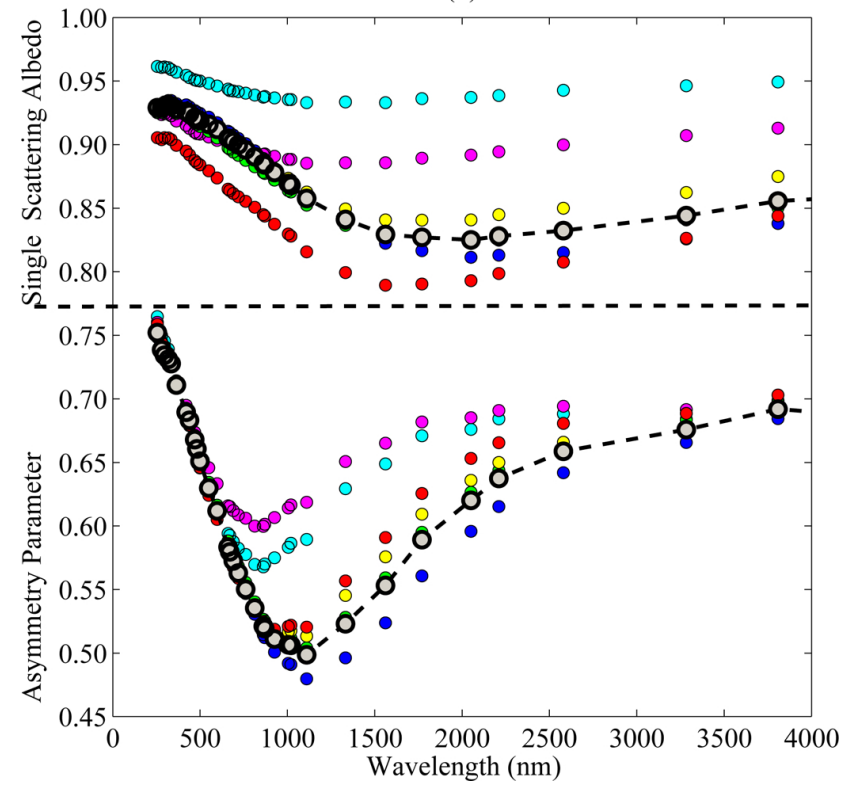

Fig. 2. Dynamic optical models (coloured circles) describing mean spectral dependence of smoke aerosol optical properties, i.e. (a) extinction efficiency, (b) single scattering albedo and asymmetry parameter obtained from a Mie code using as input the average size distribution and complex refractive index from each AERONET site. The reference optical model (dashed black line) was obtained using averaged size distribution and complex refractive index from the sites inside the burning areas of the southern part of the Amazon basin (Rio Branco, Abracos Hill and Alta Floresta).

internally mixed. Mie calculations were performed on-line with radiative transfer in order to provide the aerosol extinction, scattering and absorption spectral coefficients. The original scheme turned out to be expensive and prohibitive to run in an operational mode. Therefore, the aerosol micro- physics scheme was simplified while the radiative transfer module was kept with minor modifications. The major modification from the original version refers to the prescription of the aerosol size distribution and intensive spectral optical properties, specifically the extinction efficiency $\left(Q_{\text {ext }, \lambda}\right)$, single scattering albedo $\left(\omega_{\mathrm{o} \lambda}\right)$ and asymmetry parameter $\left(g_{\lambda}\right)$. Currently, typical spectral optical properties are obtained previously from off-line Mie calculation assuming smoke particles as homogeneous spheres and using as input climatological size distributions and complex refractive indices from AERONET sites. The smoke aerosol mass concentration forecasted by CCATT-BRAMS is converted to number concentration in the optical-radiative module assuming a prescribed density ( $\rho_{\mathrm{O}}=1.35 \mathrm{~g} \mathrm{~cm}^{-3}$, Reid et al., 1998). The aerosol size distribution is assumed to be a unimodal lognormal function based on climatological size distribution parameters obtained from AERONET retrievals. Prior prescription of smoke optical properties in CCATT-BRAMS using this approach was based on the study of Procopio et al. (2003). They developed a set of dynamic aerosol optical models defined by aerosol optical depth using AERONET sites at Alta Floresta and Abracos Hill. Rosário (2011), using several AERONET sites and longer time series, extended the development of aerosol optical properties aiming to represent the spatial variability across the major biomass burning areas in South America. Figure 2 shows the typical spectral dependence of optical properties for the sites in these areas, specifically, the southern and northeastern Amazon basin and cerrado. Main features are the higher absorption of aerosol particles from cerrado, the consistency between the sites in the southern Amazon basin and the difference between the two sites in the northeast Amazon. The reason for this difference is not yet well understood. The higher absorption of cerrado smoke aerosol has been associated with the dominance of flaming phase combustion (Yamasoe et al., 1998; Dubovik et al., 2002). These spectral optical models were calculated using an average aerosol size distribution and complex refractive index in a Mie code (Wiscombe, 1980). The spatialization of the spectral optical models in CCATT-BRAMS was performed based on the concept of anisotropic areas of influence described in Hoelzemann et al. (2009). Elsewhere in the model domain, not covered by the anisotropic areas of influence, a reference optical model was adopted. This approach was identified as dynamic aerosol optical model representation. On the other hand, the parameterization of smoke in CCATT-BRAMS using fixed optical properties for the entire model domain based on the reference optical model was designed as static aerosol optical model representation. The reference optical model was obtained using as input to Mie calculations the average of size distribution and complex refractive index from sites located in the southern Amazon basin (Rio Branco, Abracos Hill and Alta Floresta). Smoke from the southern region of the Amazon basin is the main contributor of biomass burning aerosol particles to remote regions of South America (Freitas et al., 2005; Longo et al., 2009). 
Table 1. Geographic locations of the experimental sites, dominant biomes and available data.

\begin{tabular}{|c|c|c|c|c|c|}
\hline Site & Lat $\left({ }^{\circ}\right)$ & Lon $\left(^{\circ}\right)$ & Alt. (m) & Dominant ecosystem $^{\mathrm{a}}$ & Experimental Data \\
\hline Balbina & -1.92 & -59.48 & 80.0 & Tropical Forest next to the Uatumã river & $\mathrm{AOD}(\mathrm{L} 2.0)^{\mathrm{c}}$ \\
\hline Belterra & -2.65 & -54.95 & 70.0 & Tropical Forest & $\mathrm{AOD}(\mathrm{L} 2.0)^{\mathrm{c}}$ \\
\hline Rio Branco & -9.96 & -67.87 & 212 & Tropical forest & Shortwave flux ${ }^{\mathrm{b}}(\mathrm{L} 2.0)$, AOD $(\mathrm{L} 2.0)^{\mathrm{c}}$ \\
\hline Rebio Jaru & -10.083 & -61.93 & 162 & Tropical forest surrounded by pasture & $\mathrm{AOD}(\mathrm{L} 2.0)^{\mathrm{c}}$ \\
\hline Abracos Hill & -10.76 & -62.36 & 200 & Dominated by pasture areas & Shortwave flux ${ }^{\mathrm{b}}$ (L2.0), AOD (L2.0) ${ }^{\mathrm{c}}$ \\
\hline Alta Floresta & -9.87 & -56.10 & 277 & Transition: Tropical forest to Cerrado & Shortwave flux ${ }^{\mathrm{b}}(\mathrm{L} 2.0)$, AOD $(\mathrm{L} 2.0)^{\mathrm{c}}$ \\
\hline Cuiabá & -15.73 & -56.02 & 210 & Cerrado & Shortwave flux ${ }^{b}($ L2.0), AOD (L1.5) \\
\hline Santa Cruz & -17.80 & -63.18 & 442 & Mosaic of dry forest and savanna & $\mathrm{AOD}(\mathrm{L} 2.0)^{\mathrm{c}}$ \\
\hline
\end{tabular}

${ }^{\mathrm{a}}$ Based on South America biomes map from Stone et al. (1994), ${ }^{\mathrm{b}}$ Pyranometer Kipp \& Zonen CM 21, ${ }^{\mathrm{c}}$ CIMEL CE318 sunphotometer.

Spectral aerosol optical depth $\left(\mathrm{AOD}_{\lambda}\right)$ is calculated based on the aerosol mass loading field provided by the CCATTBRAMS transport module and the spectral extinction efficiency factor stored in lookup tables. The $\mathrm{AOD}_{\lambda}$ along with $\omega_{0 \lambda}$ and $g_{\lambda}$ are used as input in the CARMA radiative transfer code in order to simulate the aerosol direct radiative effect. The CARMA two-stream radiative transfer is treated by dividing solar and infrared radiation into 32 and 19 wavelength narrow-bands, respectively. Gaseous absorption and emission are calculated using an exponential sum formulation (Toon et al., 1989). All major radiatively active atmospheric constituents - water vapour, ozone, carbon dioxide and oxygen - are taken into account. Cloud optical properties are parameterized according to Sun and Shine (1994) and Savijärvi et al. (1997) using liquid and ice particle content provided by the CCATT-BRAMS cloud microphysical module. Aerosol indirect effects were not considered in the present study; therefore, the analyzed aerosol radiative impacts are strictly associated with the direct effect. CCATTBRAMS was run three times. First, the aerosol direct radiative effect was not simulated. For the second run, the aerosol effect was turned on considering the static aerosol optical model representation based on the reference optical model (Fig. 2). The third run also included the aerosol radiative effect; however, spatially varying optical properties were prescribed following the aerosol optical dynamic model representation described above and spatially distributed based on the areas of influence described in Hoelzemann et al. (2009). The impacts of the aerosol direct radiative effect were evaluated by analyzing differences among the runs including and excluding aerosol radiative effects. All results analyzed in this study are related to the smaller domain.

\section{Experimental data and methods}

The geographical locations of the analyzed AERONET sites are depicted in Fig. 1 using as background the mean field of $\mathrm{AOD}_{550 \mathrm{~nm}}$ during the 2002 biomass burning season from the Moderate Resolution Imaging Spectroradiometer (MODIS) aboard the TERRA satellite (Levy et al., 2010). Details regarding location, dominant ecosystems and experimental data from each site are provided in Table 1. Observed total aerosol optical depth (AOD) data were taken from the AERONET direct sun inversion database. The uncertainty of the AERONET aerosol optical depth is stated to vary from 0.01 to 0.02 (Eck et al., 1999). The fine mode fraction (FMF) AOD product computed from the spectral deconvolution algorithm (SDA) methodology (O'Neill et al., 2001, 2003) was also included in the analysis. The SDA algorithm is based on the AOD spectral dependency from 380 to $870 \mathrm{~nm}$ to estimate FMF AOD, which is expected to allow a more consistent comparison with CCATT-BRAMS prognostic of AOD for smoke $\mathrm{PM}_{2.5}$ particles. The highest quality products (level 2.0) from the network were prioritized, which are pre- and post-field calibrated. The exceptions were total AOD and FMF AOD from the Cuiabá site and FMF AOD from the Alta Floresta site, for which level 2.0 products are unavailable, therefore level 1.5 data were used. Measured broadband downwelling solar radiation at the surface was obtained from SolRad-Net. The absolute uncertainty of pyranometers ranges between $2 \%$ and $3 \%$ (Schafer et al., 2002).

The comparative analysis of AOD between AERONET and CCATT-BRAMS was performed based on daily averages, while surface solar irradiances under "clear sky" conditions were compared at specific times, 12:00, 15:00 and 18:00 UTC. Solar irradiance at the surface under "clear sky" conditions is defined as the pyranometer measurements performed in absence of clouds along the path of the Sun direct beam and under minimal influence of cloud diffuse enhancement effect. The latter condition is an acknowledgment that to fully prevent cloud contamination in the Amazon basin is a challenging task. Observed irradiances were averaged over 30 min intervals centered at the mentioned times. Samples with large temporal variations in the solar irradiance at the surface were assumed to be cloud contaminated, and were therefore excluded. Additional criteria adopted to perform cloud screening are further described in Rosário et al. (2011). Cloud fractions in the Amazon basin are considerably high even during the dry season (Asner et al., 2001). This very 
likely explains the scarcity of clear sky conditions over a large period of time. For both AOD and surface solar irradiance, model results were collocated with the experimental stations assuming a window size of $90 \times 90 \mathrm{~km}$ centered at each site. Additionally, downward solar irradiance at the surface was calculated for Rio Branco, Abracos Hill, Alta Floresta and Cuiabá using AOD and column water vapour (CWV) from AERONET as input to the Santa Barbara DISORT Atmospheric Radiative Transfer (SBDART, Ricchiazzi et al., 1998) a column radiative transfer code. For cloudless conditions and at a given sun geometry, AOD and CWV variation are expected to explain most of the variability in downwelling solar irradiance at the surface. SBDART is an efficient column code for closure experiments that has been used to study radiative transfer in smoky environments in South America (Procopio et al., 2003, 2004; Rosário et al., 2011). Rosário et al. (2011) were able to reproduce the observed variability of solar irradiance when instantaneous AOD and CWV from AERONET were prescribed as inputs. The SBDART results were included in the comparison analysis between CCATT-BRAMS outputs and pyranometer measurements. Mean surface radiative flux perturbation (RFP) on a $24 \mathrm{~h}$ basis and at specific times of day was estimated averaging the instantaneous difference between modeled downward surface solar irradiance over the biomass burning season including and excluding the smoke aerosol radiative effect. The dependence of RFP efficiency (RFPE) on the adopted optical model was evaluated accordingly to the methodology of Hansell et al. (2003) and Stone et al. (2011). The method is based on linear fitting of aerosol optical depth versus the difference between downwelling solar irradiance at the surface considering and neglecting the aerosol direct radiative effect. The slope of the linear fitting provides an estimate of RFPE. An independent empirical RFPE was also calculated based on a synergy between pyranometers, sunphotometers and SBDART. Pyranometer measurements were defined to represent downwelling solar irradiance at the surface under the influence of the aerosol radiative effect. Collocated column water vapour from sunphotometers, ozone from the Total Ozone Mapping Spectrometer (TOMS) and broadband surface albedo taken from the observational study of Berbet and Costa (2003) were used as input to the SBDART radiative transfer code to simulate the solar irradiance at the surface without aerosol influence. The independent empirical RFPE was obtained as the slope from the linear fitting of the difference between measured irradiance at the surface and aerosol free irradiance calculated as a function of observed AOD. This case is free of assumptions about aerosol optical properties.

\section{Results}

\subsection{Aerosol optical depth and solar flux comparisons}

A major feature of AOD throughout the biomass burning season is its high spatial and temporal variability induced by a set of complex processes, such as random and intermittent emissions sources, atmospheric transport and removal processes and variation of the intrinsic properties of particles due to aging and mixing processes (Eck et al., 2009; Reid et al., 2005). Figure 3 compares model-calculated $\mathrm{AOD}_{550 \mathrm{~nm}}$ and observed total (Fig. 3a) and FMF (Fig. 3b) AOD $550 \mathrm{~nm}$ over distinct AERONET sites. In general, a significant agreement between model and observations is seen concerning the evolution of aerosol optical depth for the sites in the southern part of the Amazon basin and cerrado. This suggests that the model is able to capture major features of the chain of processes mentioned above in those regions. However, as expected, a better agreement is obtained when modeled results are compared with FMF $\mathrm{AOD}_{550 \mathrm{~nm}}$, especially for the Cuiabá site. Likewise for Belterra and Balbina sites, which are located in the northeastern Amazon basin (Fig. 3b). Over these two sites the model results are systematically lower when compared with AERONET total $\mathrm{AOD}_{550 \mathrm{~nm}}$ (Fig. 3a), which point out the greater relative importance of coarse mode to the total AOD during the biomass burning season in comparison with the southern part of the Amazon basin. As can be seen in Fig. 1, the northeastern region is marginally affected by the regional smoke plume. AOD peaks in November, mostly associated with local emissions. In the present study only fire emissions were considered. Therefore, one would expect the model to underestimate total AOD in that region. Hereinafter, the analysis focused on the southern Amazon basin and cerrado sites. These are located inside the core of the regional smoke plume. Regarding these sites, the critical aspect seen in the comparison with the total $\mathrm{AOD}_{550 \mathrm{~nm}}$ (Fig. 3a) is that the model struggles to capture high AOD events, especially over Alta Floresta and Cuiabá (Fig. 4a). As mentioned, the agreement between modeling and observation over Cuiabá is largely improved when modeled AOD is compared with observed FMF AOD (Figs. $3 b$ and $4 b$ ). This improvement is essentially driven by high AOD events. Over Cuiabá these high AOD events supposedly include a large contribution of coarse mode aerosols, which are not taken into account in the model. An analysis of the Ångström exponent values during these events (not shown) supported the coarse particles contribution hypothesis. Opposite to the southern region of the Amazon basin, the cerrado region (Cuiabá) is characterized by large portions of exposed soil, which under windy conditions is likely to enhance soil dust emission. On the other hand, it is worth keeping in mind that AERONET data for Cuiabá are from level 1.5 , which is only automatically cloud cleared and not manually inspected. Therefore, a possible cloud contamination cannot be ruled out. Regarding Alta Floresta, the discrepancy 
(a)
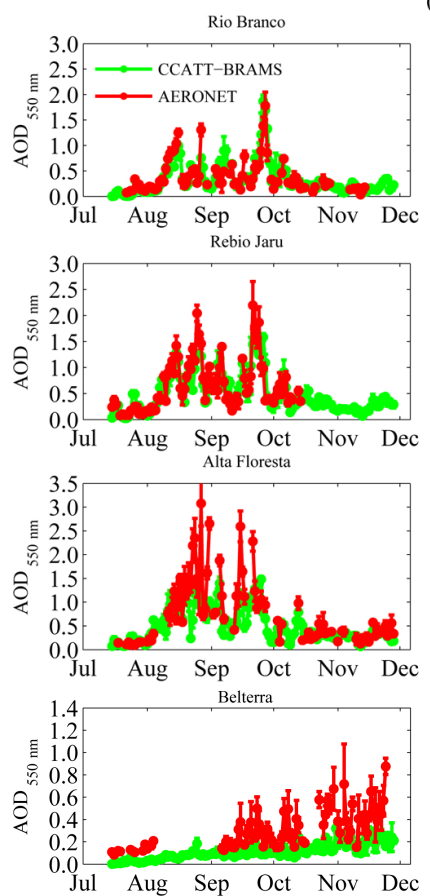
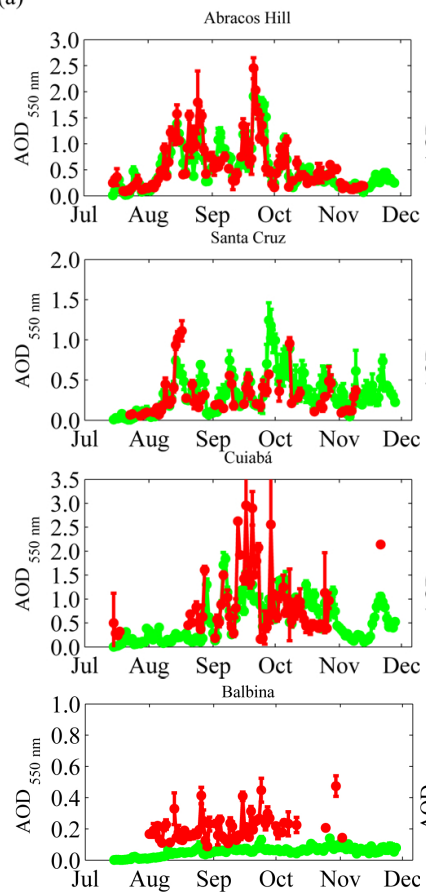

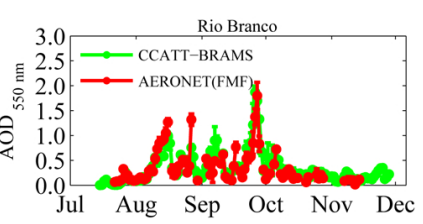

(b)
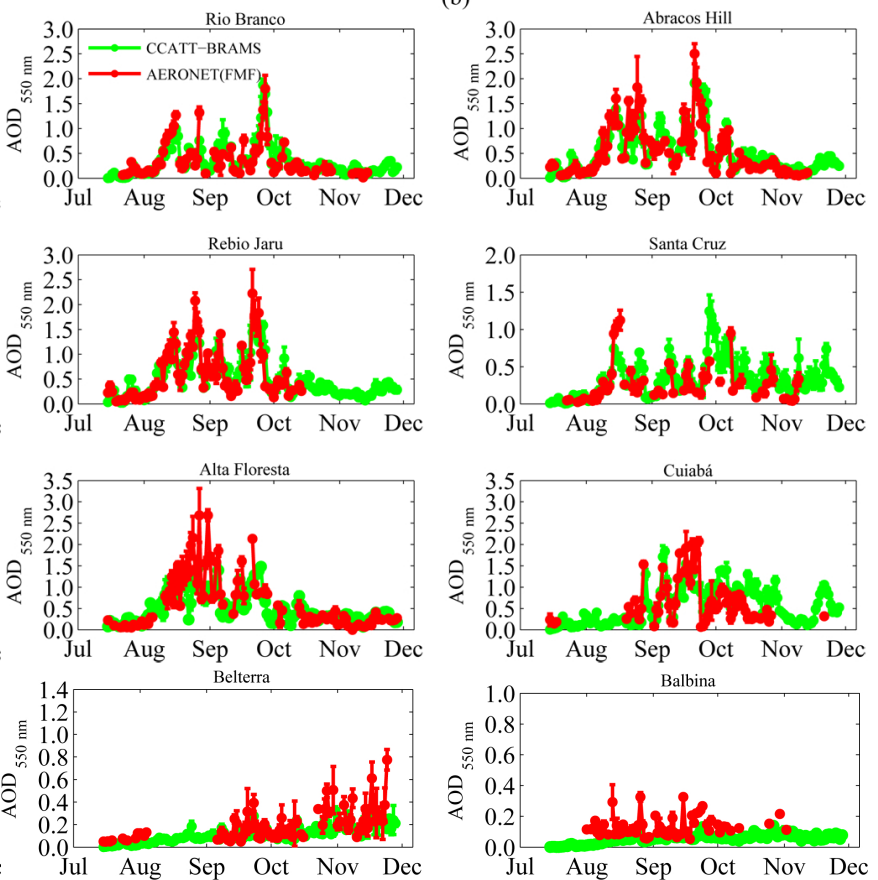

Fig. 3. Comparison of intra-seasonal variability of daily mean Aerosol Optical Depth (AOD) at 550 nm modeled by CCATT-BRAMS with (a) total and (b) Fine Mode Fraction (FMF) AOD measured by AERONET sites during the 2002 biomass burning season in South America.

(a)

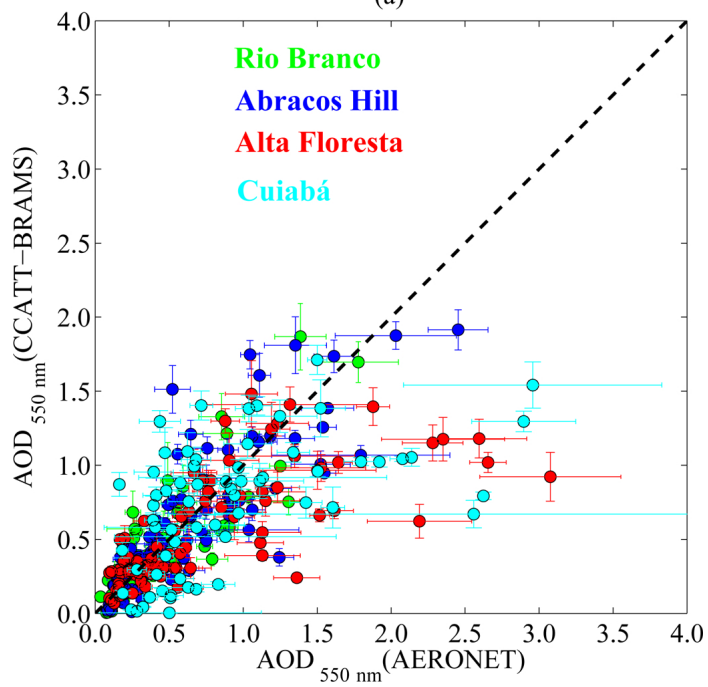

(b)

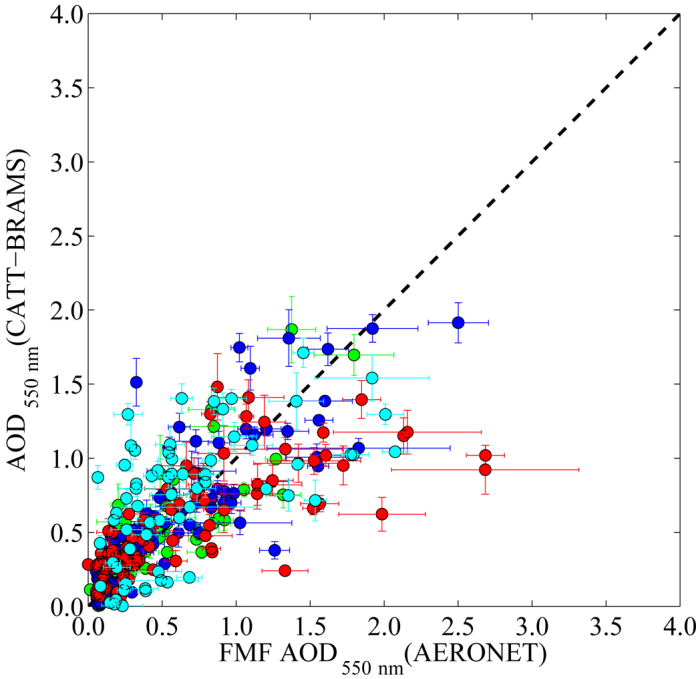

Fig. 4. Modeled daily mean aerosol optical depth at $550 \mathrm{~nm}\left(\mathrm{AOD}_{550 \mathrm{~nm}}\right.$ CCATT-BRAMS) versus observed (a) total and (b) fine mode fraction (FMF) AOD $550 \mathrm{~nm}$ (AERONET) over AERONET sites. Bars consist of standard deviation and represent daytime variability of AOD.

between model results and observation for the high AOD events that occurred at the end of August persisted even when CCATT-BRAMS results were compared with AERONET FMF AOD. This suggests that the model struggled to predict smoke aerosol loading over Alta Floresta region during that period. It is noteworthy to highlight that over the other sites located in the southern of the Amazon basin, i.e. Abra- cos Hill and Rio Branco, model AOD prediction was consistent with AERONET retrievals for the same period. Table 2 shows statistical parameters of the comparison between modeled smoke $\mathrm{AOD}_{550 \mathrm{~nm}}$ and AERONET fine mode fraction $\mathrm{AOD}_{550 \mathrm{~nm}}$. Statistical analysis was performed dividing the data in three sets: (1) all stations (Rio Branco, Abracos Hill, Alta Floresta and Cuiabá), (2) excluding Cuiabá 
Table 2. Statistics from comparison between model-calculated aerosol optical depth (AOD) and AERONET fine mode fraction (FMF) AOD. (a) All FMF AOD $550 \mathrm{~nm}$ conditions; (b) only for FMF AOD $550 \mathrm{~nm} \leq 1.0$. Root-mean-square error (RMSE), the mean absolute error (MAE), and the mean bias error.

\begin{tabular}{lrrrrrr}
\hline (a) All FMF AOD $(550 \mathrm{~nm})$ & All Sites & All Sites (no CB) & RB & AH & AF & CB \\
\hline$N$ & 348 & 284 & 83 & 102 & 99 & 64 \\
RMSE & 0.34 & 0.31 & 0.18 & 0.27 & 0.42 & 0.45 \\
MAE & 0.23 & 0.19 & 0.12 & 0.18 & 0.26 & 0.36 \\
Bias & -0.01 & 0.01 & -0.03 & -0.03 & 0.08 & -0.09 \\
\hline (b) FMF AOD $(550 \mathrm{~nm}) \leq 1.0$ & All Sites & All Sites (no CB) & RB & AH & AF & CB \\
\hline$N$ & 292 & 240 & 78 & 84 & 78 & 52 \\
RMSE & 0.24 & 0.19 & 0.16 & 0.21 & 0.19 & 0.40 \\
MAE & 0.17 & 0.13 & 0.11 & 0.14 & 0.14 & 0.33 \\
Bias & -0.09 & -0.06 & -0.04 & -0.07 & -0.07 & -0.22 \\
\hline
\end{tabular}

and keeping all the other sites and (3) for each station individually. In spite of the better agreement obtained when the model results are compared with observed FMF AOD, CCATT-BRAMS performance over Cuiabá is lower than over the sites in the southern of the Amazon basin, mainly for moderate and low AOD conditions. Table 2 also shows statistics excluding extreme events by defining a threshold $\left(\mathrm{AOD}_{550 \mathrm{~nm}} \leq 1.0\right)$. Extreme AOD events represent roughly $20 \%$ of the dataset. It is clear that the worst $(\mathrm{RMSE}=0.34)$ and the best $(\mathrm{RMSE}=0.19)$ comparison between model outputs and observations when considering all stations are obtained when the Cuiabá site and extreme events are included and excluded in the analysis, respectively.

Unlike sunphotometers, due to relatively coarse grid resolution, the model is not expected to capture highly dense and localized plumes, which could explain the divergence between model and AERONET observation over Alta Floresta during high AOD events. However, the persistence of divergences over large time periods suggests that modeling aspects, beyond grid characteristics, may play an important role in the observed differences. Given the magnitude of the differences, variability in particle intensive optical properties are unlikely to play a major role. Emissions very likely are the critical aspect on this issue. Omission or misrepresentation of fire spots can induce important errors in the emissions and consequently in the aerosol loading field. Imageacquisition geometry and cloud coverage conditions have been pointed out as important issues in this matter (Schroeder et al., 2005, 2008). By comparing satellite fire spot retrievals with aircraft observations over the southwest Amazon basin, Pantoja and Brown (2007) showed that the divergences between the two data sources were consistently associated with omission of satellite fire spots. Hyer and Reid (2009) discuss the role of satellite data products with varying spatial resolution on biomass burning emissions modeling. Using 120-m land cover data for the Amazon basin, they estimated the probability of accurate classification of individual fires at $88 \%$ for MODIS and $74 \%$ for GOES. They bring up the fact that emission biases caused by spatial error in satellite active fire location data vary with regional distribution of fire type and are prone to occur in heterogeneous landscapes. Alta Floresta, once an entirely forested region, has been subjected to very high deforestation rates. This resulted in a fragmented landscape containing forest patches surrounded by pasture fields. Emissions based on remote sensing of fire brought large improvements to smoke modeling in South America when compared with conventional databases (Longo et al., 2010). However, the spatial and temporal scale of fire occurrence might still impose a considerable detection error. Figure 5 compares the modeled $\mathrm{AOD}_{550 \mathrm{~nm}}$ field with retrievals by MODIS aboard the TERRA satellite from 24 to $29 \mathrm{Au}-$ gust, the period characterized by major divergences between the model and AERONET at Alta Floresta. MODIS well known tendency to overestimate AOD for South America regional smoke plume (Hoelzemann et al., 2009; Levy et al., 2010) was corrected using Hoelzemann et al. (2009) linear regression parameters (slope and intercept) obtained comparing AERONET and MODIS retrievals over South America during biomass burning season. Regionally, the spatial distribution of smoke is relatively well captured by the model, while locally, mainly in the emission sources areas, significant differences are observed. MODIS overpass geometry over Alta Floresta during the analyzed period was frequently problematic, which is an issue for fire spot detection. This corroborates the hypothesis that major divergences between the model results and AERONET FMF AOD at Alta Floresta are very likely induced by emissions issues.

Figures 6 and 7 show comparisons between modelcalculated and observed solar irradiance at the surface under cloud-free conditions. Observational data is scarce during the afternoon (15:00 UTC, 18:00 UTC) mainly due to the increase in cloudiness. Consequently, the AOD signature on surface solar irradiance is better identified looking at morning data (12:00 UTC). The SBDART estimation of solar irradiance at the surface using AOD and column water vapour from AERONET sunphotometers as input is also plotted. 
(a)

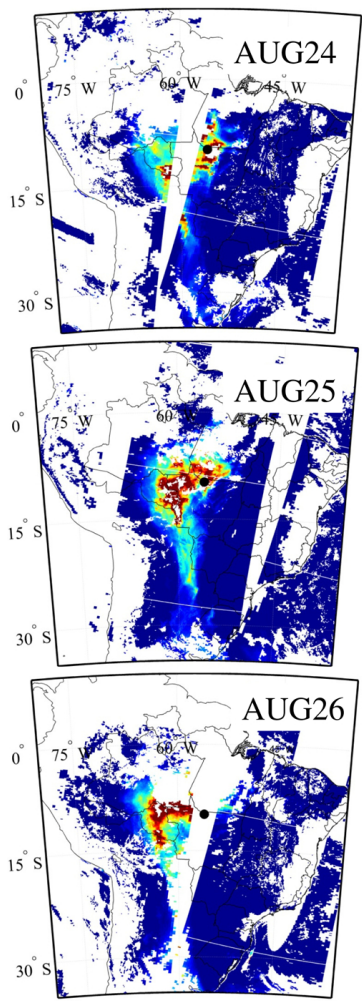

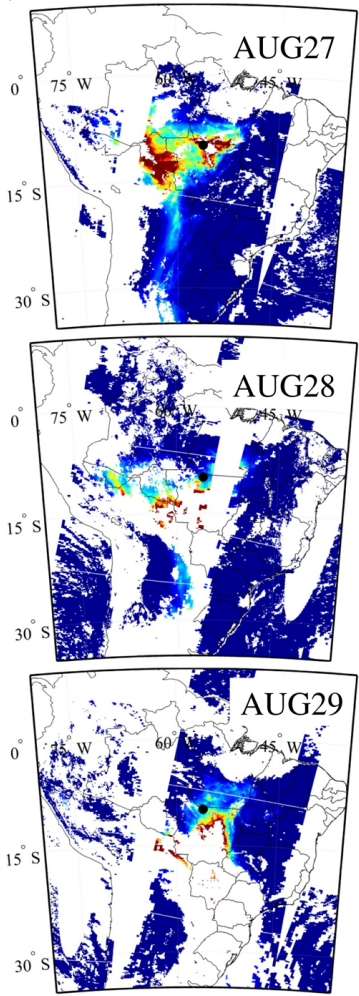

(b)
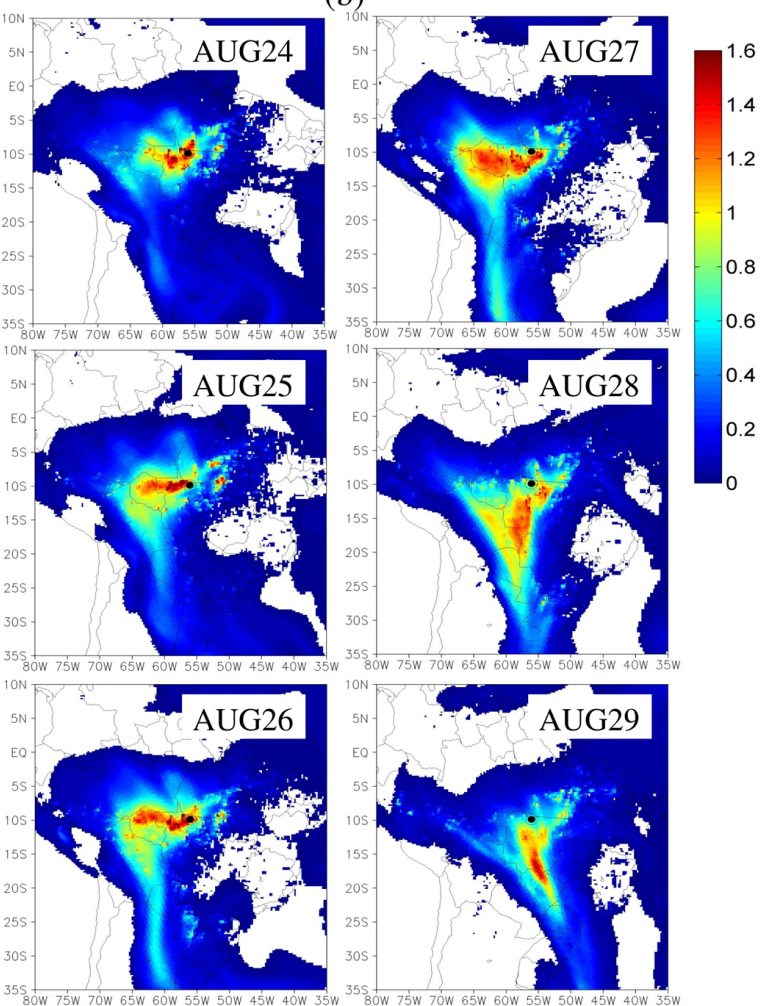

Fig. 5. Comparison between spatial distributions of aerosol optical depth at $550 \mathrm{~nm}\left(\mathrm{AOD}_{550 \mathrm{~nm}}\right)$ retrieved by (a) MODIS aboard Terra satellite and modeled by (b) CCATT-BRAMS from 24 to 29 August, period when major discrepancies occurred between the model results and AERONET AOD retrievals.
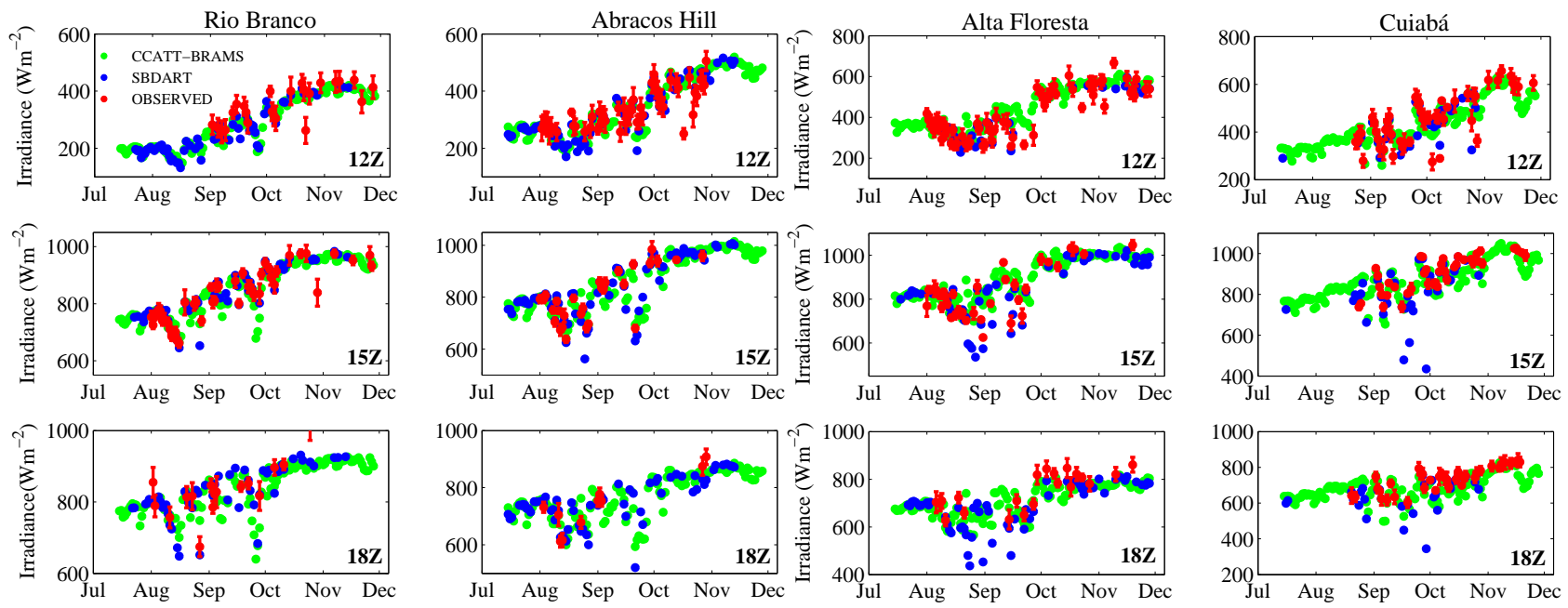

Fig. 6. Modeled (CCATT-BRAMS, SBDART) versus observed downwelling solar irradiance at the surface under cloud-free conditions. SBDART results were obtained using as input aerosol optical depth and column water vapour from AERONET.

Main trends in solar irradiance at surface are in general well captured by the model. This is an outcome of the model's ability to predict the major features of AOD variability. Nevertheless, non-negligible discrepancies still occur. Figure 8 shows differences between measured and modeled solar ir- radiance as a function of collocated differences between observed and modeled AOD. The linear relationship highlights the dominance of aerosol optical depth as the major source of uncertainty when it comes to modeling of solar irradiance at the surface. Table 3 shows statistics of the comparison 
Table 3. Statistics from comparison between model-calculated broadband solar irradiance at the surface and pyranometer measurements. Root-mean-square error (RMSE), the mean absolute error (MAE), and the mean bias error are presented.

\begin{tabular}{lcccc}
\hline $\begin{array}{l}\text { Solar Irradiance at } \\
\text { the surface }\left(\mathrm{Wm}^{-2}\right)\end{array}$ & All Sites & $\begin{array}{c}\text { All Sites } \\
(\mathrm{AOD} \leq 1.0)\end{array}$ & $\begin{array}{c}\text { All Sites } \\
\text { (no CB) }\end{array}$ & $\begin{array}{c}\text { All Sites } \\
\text { (no CB and } \\
\text { AOD } \leq 1.0)\end{array}$ \\
\hline$N$ & 260 & 206 & 194 & 156 \\
RMSE $\left(\mathrm{Wm}^{-2}\right)$ & 45 & 40 & 40 & 31 \\
MAE $\left(\mathrm{Wm}^{-2}\right)$ & 33 & 30 & 29 & 24 \\
Bias $\left(\mathrm{Wm}^{-2}\right)$ & 6 & 11 & 0.7 & 7 \\
\hline
\end{tabular}

between the model and pyranometers. Yet again, the best scenario $\left(\mathrm{RMSE}=31 \mathrm{Wm}^{-2}\right.$ ) occurs when the Cuiabá site and extreme AOD events are excluded from the analysis. When all data were considered the agreement between the model and the observations decreased $\left(\mathrm{RMSE}=45 \mathrm{Wm}^{-2}\right.$ ). The Cuiabá site performed worse for the irradiance intercomparison than the other sites, data not shown. The observed larger positive discrepancies may be related to cloud contamination, in spite of the application of a cloud screening procedure to both pyranometer and sun photometer datasets. However, they are not expected to significantly alter the general assessments of the present analysis. In summary, the comparisons show that CCATT-BRAMS was able to reproduce the main features of the AOD field associated with the regional smoke plume and to capture its seasonal variability and impacts on the downwelling solar energy at the surface. The major difficulty seems to be related to extreme smoke events $\left(\mathrm{AOD}_{550 \mathrm{~nm}}>1.0\right)$. Although these events in general represent less than $20 \%$ of the total AERONET samples from the direct sun inversion, their impacts are significant. Therefore the aspects behind the struggling of the model need to be addressed. A conclusive analysis of the impact of satellite scan geometry and spatial resolution and clouds on emissions modelling needs to be performed. Apparently, the days in the present study with major deviations coincided with smoky areas being imaged under larger scan angles (W. Schroeder, personal communication, 2009).

\subsection{Radiative flux perturbation efficiency and surface RFP}

Radiative flux perturbation efficiency (RFPE) is a metric of the sensitivity of the aerosol radiative flux perturbation to aerosol types and is primarily controlled by intrinsic aerosol properties. Figure 9 shows regression plots of AOD versus differences between solar irradiance at the surface neglecting and considering aerosol direct radiative effects. The results are shown for noontime when the instantaneous RFP is expected to be high. The slopes represent estimates of mean RFPE. Regressions are presented for the aerosol direct radiative effect modeled using the reference optical model and the optical models for Rio Branco, Abracos Hill, Alta Flo-

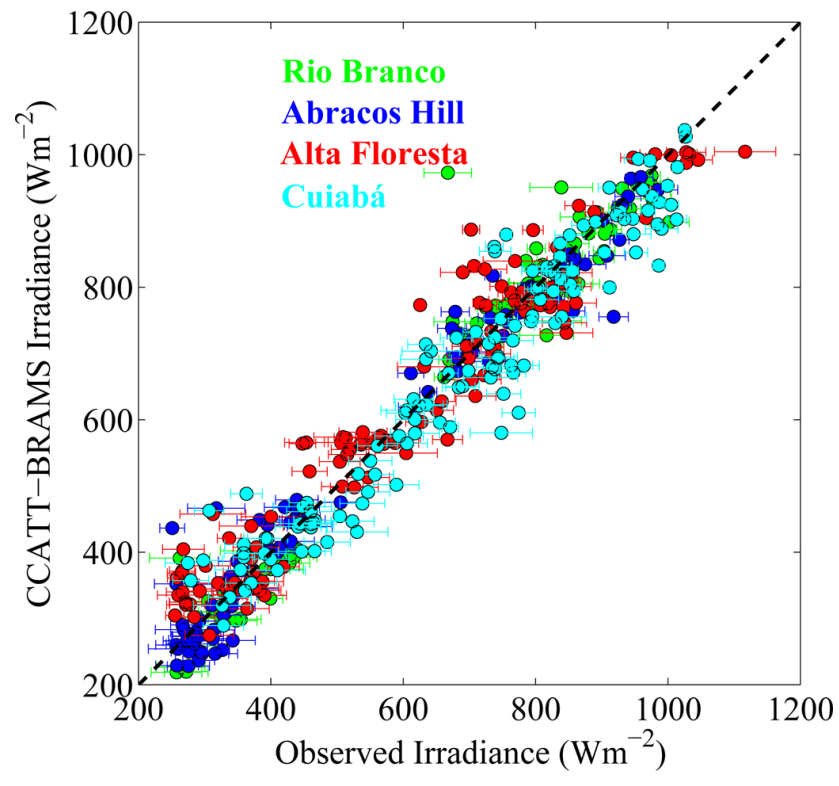

Fig. 7. Model-calculated (CCATT-BRAMS) versus observed downwelling solar radiation at the surface under cloud-free conditions at AERONET sites (Rio Branco, Abracos Hill, Alta Floresta and Cuiabá).

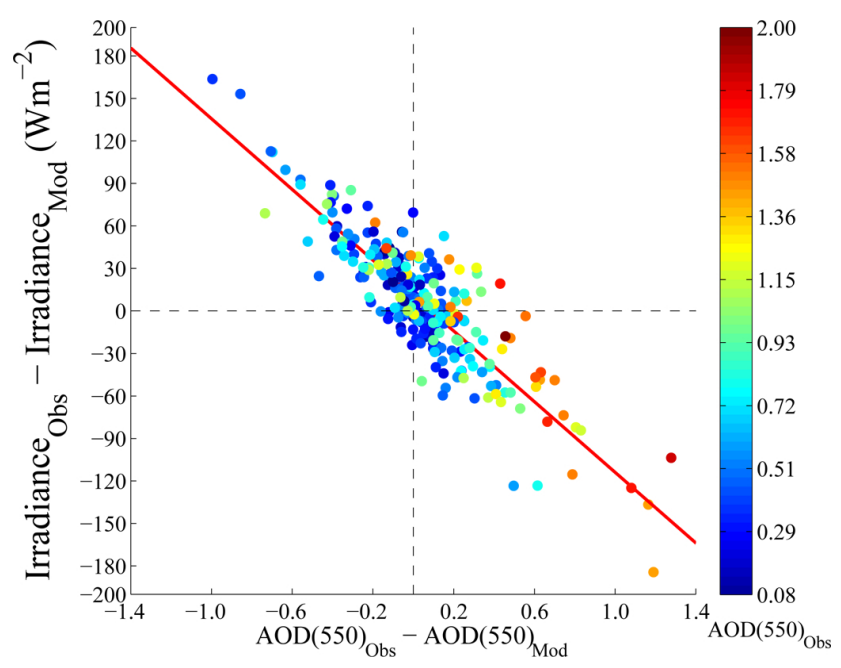

Fig. 8. Difference between downward observed and modeled surface solar irradiance versus difference between observed and modeled aerosol optical depth (AOD) as a function of observed AOD under cloud-free conditions.

resta and Cuiabá previously shown in Fig. 2. For the sites inside the Amazon basin the RFPE varied between -154 and $-163 \mathrm{Wm}^{-2} / \mathrm{AOD}_{550 \mathrm{~nm}}$. The RFPE for the reference optical model $\left(-158 \mathrm{Wm}^{-2} / \mathrm{AOD}_{550 \mathrm{~nm}}\right)$ is consistently in the middle of the range. An independent empirical estimate based on pyranometer and sunphotometer measurements for the southern Amazon basin is also shown $\left(-141 \mathrm{Wm}^{-2} / \mathrm{AOD}_{550 \mathrm{~nm}}\right)$ in Fig. 9 labeled as observed. Smoke aerosol in cerrado (Cuiabá) has higher RFPE $\left(-187 \mathrm{Wm}^{-2} / \mathrm{AOD}_{550 \mathrm{~nm}}\right)$ mainly 
Table 4. Estimative of smoke aerosol Radiative Flux Perturbation Efficiency (RFPE) obtained in the present study and several estimates from previously published studies.

\begin{tabular}{lll}
\hline $\operatorname{RFPE}\left(\mathrm{Wm}^{-2} / \mathrm{AOD}_{\lambda}\right)^{*}$ & Description & Reference \\
\hline$-154(\lambda=550 \mathrm{~nm})$ & Abracos Hill & This work \\
$-163(\lambda=550 \mathrm{~nm})$ & Rio Branco & This work \\
$-163(\lambda=550 \mathrm{~nm})$ & Alta Floresta & This work \\
$-158(\lambda=550 \mathrm{~nm})$ & Southern Amazon basin (Model) & This work \\
$-141(\lambda=550 \mathrm{~nm})$ & Southern Amazon basin (Empirical) & This work \\
$-187(\lambda=550 \mathrm{~nm})$ & Cerrado ecosystem & This work \\
$-145(\lambda=500 \mathrm{~nm})$ & Southern Amazon basin & Schafer et al. (2002) \\
$-210(\lambda=500 \mathrm{~nm})$ & Africa Savanna & Schafer et al. (2002) \\
$-148 \pm 44(\lambda=550 \mathrm{~nm})$ & Smoke/dust: Central Africa & García et al. (2012) \\
$-223 \pm 39(\lambda=550 \mathrm{~nm})$ & Africa Savanna & García et al. (2012) \\
$-152 / 194(\lambda=500 \mathrm{~nm})$ & Boulder, Colorado & Stone et al. $(2011)$ \\
\hline
\end{tabular}

* at noon time

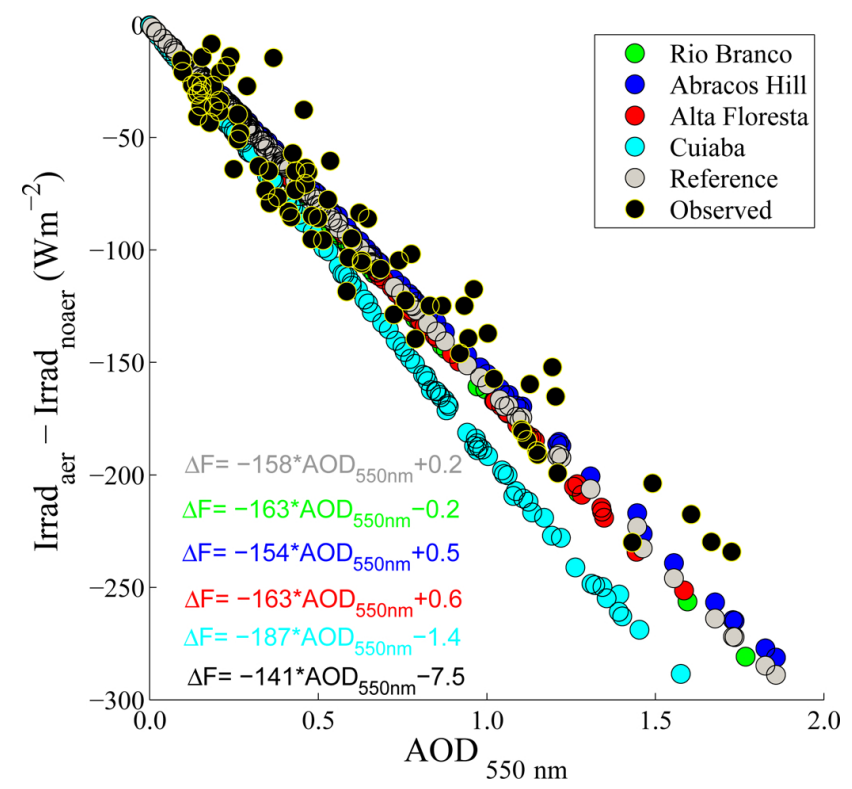

Fig. 9. Linear fitting of aerosol optical depth at $550 \mathrm{~nm}$ versus the difference between downward surface solar irradiance considering ( Irrad $\left._{a e r}\right)$ and neglecting ( $\left.\operatorname{Irrad}_{\text {noaer }}\right)$ the aerosol direct radiative effect. For the observed case, denominated as the empirical approach, Irrad $_{\text {aer }}$ consists of pyranometer measurements and Irrad noaer was estimated using the SBDART code, prescribing water vapour and ozone from observations and turning off aerosol effects. The slopes represent estimates of aerosol radiative flux perturbation efficiency (RFPE).

due to its larger absorption. The obtained RFPE are compared with values found in the literature (Table 4). Concerning the southern region of the Amazon basin, the obtained RFPE are higher than empirical values estimated by Schafer et al. (2002) for Abracos Hill and Alta Floresta sites but consistent with the overall RFPE variability. Regarding the difference between the empirical RFPEs and those obtained us- ing climatological optical models, one can argue that it is likely due to the fact that the former has been obtained for particular years. Figure 10 shows $24 \mathrm{~h}$ smoke surface RFP averaged over the biomass burning season. Results are presented for both model runs considering static and varying optical properties models. As expected, major differences between both approaches are seen downwind of the Amazon basin. On average, single scattering albedos retrieved by downwind AERONET sites are lower than values retrieved inside the southern region of the Amazon basin. The spatial range of daily mean surface RFP in the southern Amazon basin $\left(-35\right.$ to $\left.-50 \mathrm{Wm}^{-2}\right)$ is consistent with Procópio et al. (2004) results $\left(-34.5\right.$ to $\left.-48 \mathrm{Wm}^{-2}\right)$. Regionally, the smoke surface RFP varies from $-55 \mathrm{Wm}^{-2}$, in areas heavily affected by biomass burning emissions, to $-10 \mathrm{Wm}^{-2}$ near the southeast Brazilian coast. In the northwestern portion of the Amazon basin, the surface shortwave flux perturbation is also $-10 \mathrm{Wm}^{-2}$. Figure 11 shows mean surface RFP at specific times (12:00, 15:00, 18:00 and 21:00 UTC) in order to highlight the daytime cycle. Maximum perturbation occurs at noontime (15:00 UTC) and it is around $-100 \mathrm{Wm}^{-2}$ in areas close to the emission sources. The diurnal cycle of the impact on the lower troposphere net radiative heating profile is shown (Fig. 12) through a cross section at longitude $57^{\circ} \mathrm{W}$, all along the South American continent, from clean areas in northern South America, crossing biomass burning regions in central regions, and up to the northern region of Argentina at $35^{\circ} \mathrm{S}$. The net effect is essentially a warming of the atmosphere. As expected, higher impacts are observed at noontime when a larger amount of solar energy is available. Net radiative heating rates when smoke is included can be twice that of the aerosol free case. The net impact of both a reduction in solar energy at the surface and enhancement of radiative heating rate induced by the regional smoke on the South American climate is still uncertain and a subject of research. Accurate modeling of the spatio-temporal distribution of the regional smoke loading and its intrinsic radiative 
(a)

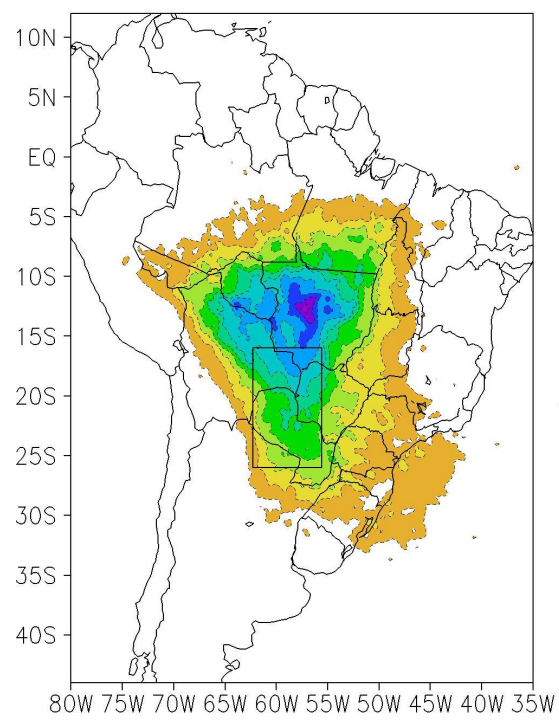

(b)

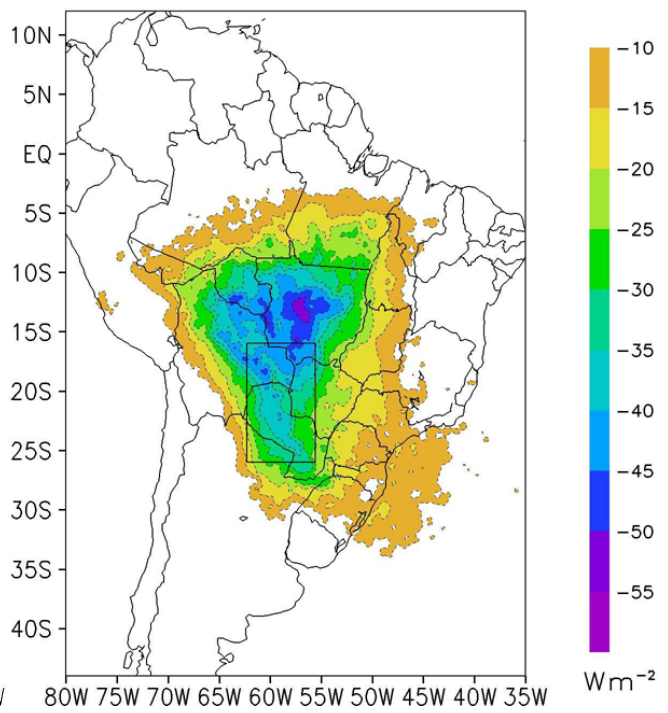

Fig. 10. Biomass burning season mean $24 \mathrm{~h}$ surface radiative flux perturbation calculated by averaging differences between downward surface solar irradiance including and excluding the aerosol direct radiative effect. (a) Using a static aerosol optical properties model and (b) prescribing spatially varying optical properties models. The black boxes highlight the region where major differences are expected between assumptions (a) and (b).
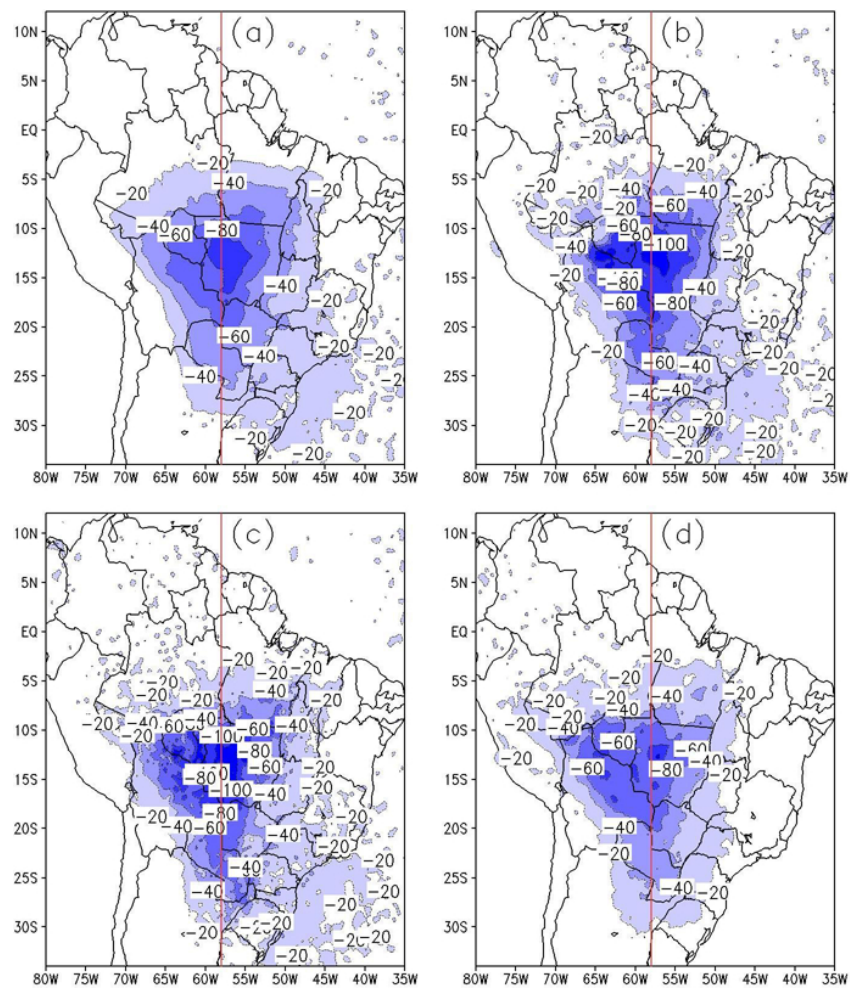

Fig. 11. Biomass burning season mean surface radiative flux perturbation at specific times calculated by averaging differences between the downward surface solar irradiance including and excluding the aerosol direct radiative effect. (a) 12:00 UTC, (b) 15:00 UTC, (c) 18:00 UTC and (d) 21:00 UTC. properties remains a challenging task. Results of the present study indicated that the CCATT-BRAMS model is able to consistently simulate major features of AOD variability related to the regional smoke plume as well as the impact on downward shortwave radiation at the surface. However, important deviations from observations are still occurring. Ongoing studies are expected to tackle these issues.

\section{Final remarks}

The present paper describes a modeling effort to simulate the aerosol optical depth of the regional smoke produced during the 2002 biomass burning season and the associated surface shortwave flux perturbation in the Amazon basin and cerrado ecosystem. The CCATT-BRAMS model developed at the National Institute for Space Research for air quality and climate studies was used. CCATT-BRAMS is a fully coupled on-line model, which allows feedbacks between the aerosol radiative effect and other atmospheric processes. Generally, comparisons between model-calculated variability of AOD and data from AERONET showed significant agreement. The model was able to capture the major features of AOD throughout the burning season over most of the analyzed AERONET sites. The main shortcomings were the underestimation of AOD in the northeastern region of the Amazon basin and the difficulty of the model in capturing extreme AOD events $\left(\mathrm{AOD}_{550 \mathrm{~nm}}>1.0\right)$ in the cerrado region (Cuiabá) and the transition areas from primary forest to cerrado (Alta Floresta). The AOD underestimation over the 

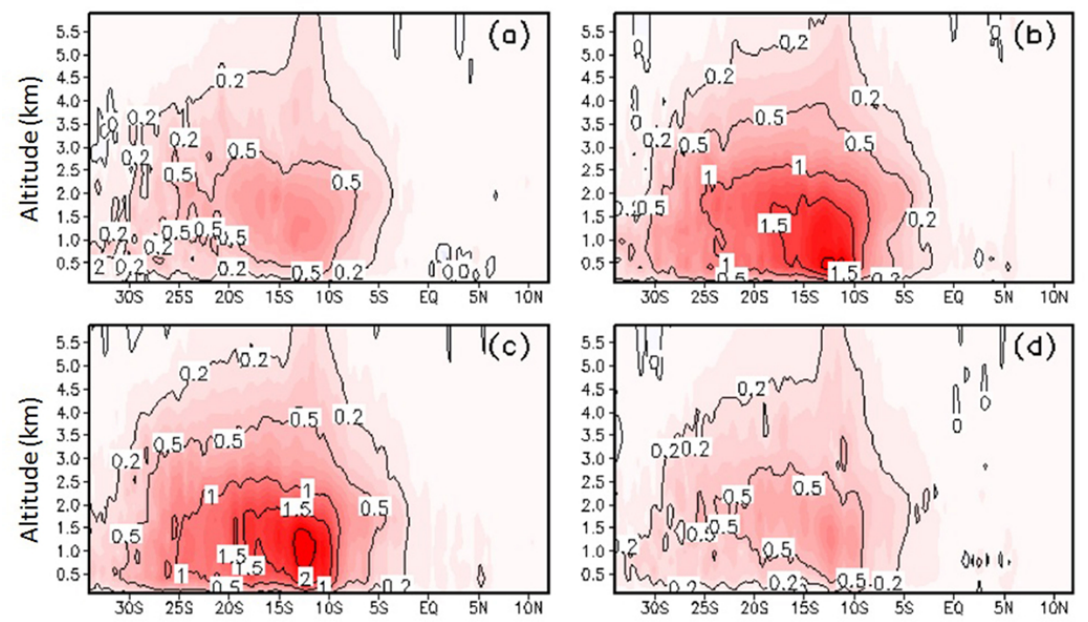

Fig. 12. North-South cross section (red line Fig. 10) average profile of the differences $\left(\mathrm{Kday}^{-1}\right)$ between modeled net radiative heating/cooling rates including and excluding the aerosol direct radiative effect over the biomass burning season at (a) 12:00 UTC, (b) 15:00 UTC, (c) 18:00 UTC and (d) 21:00 UTC.

northeastern of the Amazon basin was primarily related to the omission of coarse mode aerosol in the model simulation. Likewise, the discrepancy between the model and observation during extreme AOD events over the cerrado. However, over Alta Floresta region the divergences during high AOD events are associated with the model's problem in predict smoke fine mode aerosols. Accordingly to the AERONET direct sun inversion, extreme events represent roughly $20 \%$ of conditions observed during the biomass burning season; however, their radiative impacts are huge. They can reduce solar irradiance at the surface by up to $300 \mathrm{Wm}^{-2}$. The main suspect of the model difficulty in capturing these events is related to emissions estimation. The omission of fire spots, satellite geometry issues and localized emission sources very likely explains this deficiency. The root-mean-square error (RMSE) between modeled and observed fine mode fraction AOD decreased from 0.34 to 0.19 when extreme AOD events and the Cuiabá site were excluded from the analysis. A similar trend was observed when the modeled downwelling solar irradiance at the surface was compared with pyranometer measurements. Better agreement was achieved between CCATT-BRAMS and observations when the data was restricted to irradiance measured for $\mathrm{AOD}_{550 \mathrm{~nm}}$ lower than 1.0. Ongoing modeling simulations and planned future field experiments are expected to allow more conclusive analysis of this aspect. Radiative flux perturbation efficiency (RFPE) obtained using space varying optical models was compared with RFPE using a static optical model prescription. The static model consisted of typical optical properties of smoke aerosol produced in the southern Amazon basin. Major impacts on surface shortwave flux perturbation were observed downwind of the Amazon basin where smoke aerosol plumes are on average more absorbing. Mean $24 \mathrm{~h}$ surface radiative flux perturbation induced by the regional smoke plume varied from -55 to $-10 \mathrm{Wm}^{-2}$, from biomass burning areas to remote regions in the southeast of Brazil and in the northwest portion of the Amazon basin. In areas close to the emission sources, the enhancement of the net radiative heating rate by the regional smoke was as much as double the aerosol-free condition. Our results pointed out the ability of CCATT-BRAMS to simulate major spatio-temporal features of the aerosol optical depth field associated with South American regional smoke, despite the simplified aerosol microphysics adopted. The observed performance is a consequence of recent improvements of regional smoke dynamic in the model, particularly emission regionalization (Longo et al., 2010) and the inclusion of sub-grid scale plume rise from vegetation fires (Freitas et al., 2007). Nevertheless, shortcomings were also observed and emissions are still a critical aspect and a matter of continuing research. Ongoing developments of CCATT-BRAMS and its emissions module are expected to improve the modeling of regional aerosol chemistry in South America.

Acknowledgements. The first author wishes to thank CNPq (Conselho Nacional de Desenvolvimento Científico e Tecnológico) for the financial support (processes 140559/2007-8; 201177/2009-9). Additional thanks to AERONET and the SolRad-Net teams for making available the data used in this study. M. Yamasoe acknowledges FAPESP (Fundação de Amparo à Pesquisa do Estado de São Paulo), process number 06-56550-5 and CAPES/PROEX (Coordenação de Aperfeiçoamento de Pessoal de Nível Superior/Programa de Excelência Acadêmica).

Edited by: G. Feingold 


\section{References}

Andreae, M. and Merlet, P.: Emission of trace gases and aerosols from biomass burning, Global Biogeochem. Cy., 15, 955-966, 2001.

Asner, G. P.: Cloud cover in Landsat observations of the Brazilian Amazon, Int. J. Remote Sens., 22, 3855-3862, doi:10.1080/01431160010006926, 2001.

Belward, A.: The IGBP-DIS global $1 \mathrm{~km}$ land cover data set (DISCover)-proposal and implementation plans, IGBP-DIS Working Paper No. 13, Toulouse, France, 1996.

Berbet, M. L. C. and Costa, M. H.: Climate Change after Tropical Deforestation: Seasonal Variability of Surface Albedo and Its Effects on Precipitation Change, J. Climate, 16, 2099-2104, doi:10.1175/1520-0442(2003)016<2099:ccatds $>2.0$.co;2, 2003.

Cavalcanti, I. F. A., Marengo, J. A., Satyamurty, P., Nobre, C. A., Trosnikov, I., Bonatti, J. P., Manzi, A. O., Tarasova, T., Pezzi, L. P., D’Almeida, C., Sampaio, G., Castro, C. C., Sanches, M. B., and Camargo, H.: Global climatological features in a simulation using CPTEC/COLA AGCM, J. Climate, 15, 2965-2988, 2002.

Colarco, P. R., Toon, O. B., Torres, O., and Rasch, P. J.: Determining the UV imaginary index of refraction of Saharan dust particles from Total Ozone Mapping Spectrometer data using a three-dimensional model of dust transport, J. Geophys. Res., 107, 4289, doi:10.1029/2001jd000903, 2002.

Dubovik, O., Holben, B., Eck, T. F., Smirnov, A., Kaufman, Y. J., King, M. D., Tanré, D., and Slutsker, I.: Variability of Absorption and Optical Properties of Key Aerosol Types Observed in Worldwide Locations, J. Atmos. Sci., 59, 590-608, doi:10.1175/15200469(2002)059<0590:voaaop>2.0.co;2, 2002.

Eck, T. F., Holben, B. N., Reid, J. S., Dubovik, O., Smirnov, A., O'Neill, N. T., Slutsker, I., and Kinne, S.: Wavelength dependence of the optical depth of biomass burning, urban, and desert dust aerosols, J. Geophys. Res., 104, 31333-31349, doi:10.1029/1999jd900923, 1999.

Eck, T. F., Holben, B. N., Reid, J. S., Sinyuk, A., Hyer, E. J., O’Neill, N. T., Shaw, G. E., Vande Castle, J. R., Chapin, F. S., Dubovik, O., Smirnov, A., Vermote, E., Schafer, J. S., Giles, D., Slutsker, I., Sorokine, M., and Newcomb, W. W.: Optical properties of boreal region biomass burning aerosols in central Alaska and seasonal variation of aerosol optical depth at an Arctic coastal site, J. Geophys. Res., 114, D11201, doi:10.1029/2008jd010870, 2009.

Forster, P., Ramaswamy, V., Artaxo, P., Berntsen, T., Betts, R., Fahey, D. W., Haywood, J., Lean, J., Lowe, D. C., Myhre, G., Nganga, J., Prinn, R., Raga, G., Schulz, M., and Van Dorland, R.: Changes in Atmospheric Constituents and in Radiative Forcing, in: Climate Change 2007: The Physical Science Basis. Contribution of Working Group I to the Fourth Assessment Report of the Intergovernmental Panel on Climate Change, edited by: Solomon, S., Qin, D., Manning, M., Chen, Z., Marquis, M., Averyt, K. B., Tignor, M., and Miller, H. L., Cambridge University Press, Cambridge, United Kingdom and New York, NY, USA, 2007.

Freitas, S. R., Longo, K. M., Silva Dias, M., Silva Dias, P., Chatfield, R., Prins, E., Artaxo, P., Grell, G., and Recuero, F.: Monitoring the transport of biomass burning emissions in South America, Environ. Fluid Mech., 5, 135-167, doi:10.1007/s10652-0050243-7, 2005.
Freitas, S. R., Longo, K. M., Chatfield, R., Latham, D., Silva Dias, M. A. F., Andreae, M. O., Prins, E., Santos, J. C., Gielow, R., and Carvalho Jr., J. A.: Including the sub-grid scale plume rise of vegetation fires in low resolution atmospheric transport models, Atmos. Chem. Phys., 7, 3385-3398, doi:10.5194/acp-7-3385-2007, 2007.

Freitas, S. R., Longo, K. M., Silva Dias, M. A. F., Chatfield, R., Silva Dias, P., Artaxo, P., Andreae, M. O., Grell, G., Rodrigues, L. F., Fazenda, A., and Panetta, J.: The Coupled Aerosol and Tracer Transport model to the Brazilian developments on the Regional Atmospheric Modeling System (CATT-BRAMS) - Part 1: Model description and evaluation, Atmos. Chem. Phys., 9, $2843-$ 2861, doi:10.5194/acp-9-2843-2009, 2009.

Freitas, S. R., Longo, K. M., Alonso, M. F., Pirre, M., Marecal, V., Grell, G., Stockler, R., Mello, R. F., and Sánchez Gácita, M.: PREP-CHEM-SRC - 1.0: a preprocessor of trace gas and aerosol emission fields for regional and global atmospheric chemistry models, Geosci. Model Dev., 4, 419-433, doi:10.5194/gmd-4419-2011, 2011.

García, O. E., Díaz, J. P., Expósito, F. J., Díaz, A. M., Dubovik, O., Derimian, Y., Dubuisson, P., and Roger, J.-C.: Shortwave radiative forcing and efficiency of key aerosol types using AERONET data, Atmos. Chem. Phys., 12, 5129-5145, doi:10.5194/acp-125129-2012, 2012.

Giglio, L., Descloitres, J., Justice, C. O., and Kaufman, Y. J.: An enhanced contextual fire detection algorithm for MODIS, Remote Sens. Environ., 87, 273-282, 2003.

Hansell, R. A., Tsay, S.-C., Ji, Q., Liou, K. N., and Ou, S.-C.: Surface aerosol radiative forcing derived from collocated groundbased radiometric observations during PRIDE, SAFARI, and ACE-Asia, Appl. Optics, 42, 5533-5544, 2003.

Haywood, J. and Boucher, O.: Estimates of the direct and indirect radiative forcing due to tropospheric aerosols: A review, Rev. Geophys., 38, 513-543, doi:10.1029/1999rg000078, 2000.

Hoelzemann, J. J., Longo, K. M., Fonseca, R. M., do Rosário, N. M. E., Elbern, H., Freitas, S. R., and Pires, C.: Regional representativity of AERONET observation sites during the biomass burning season in South America determined by correlation studies with MODIS Aerosol Optical Depth, J. Geophys. Res., 114, D13301, doi:10.1029/2008jd010369, 2009.

Holben, B. N., Eck, T. F., Slutsker, I., Tanré, D., Buis, J. P., Setzer, A., Vermote, E., Reagan, J. A., Kaufman, Y. J., Nakajima, T., Lavenu, F., Jankowiak, I., and Smirnov, A.: AERONET - A Federated Instrument Network and Data Archive for Aerosol Characterization, Remote Sens. Environ., 66, 1-16, doi:10.1016/s0034-4257(98)00031-5, 1998.

Hyer, E. J. and Reid, J. S.: Baseline uncertainties in biomass burning emission models resulting from spatial error in satellite active fire location data, Geophys. Res. Lett., 36, L05802, doi:10.1029/2008GL036767, 2009.

Kinne, S., Schulz, M., Textor, C., Guibert, S., Balkanski, Y., Bauer, S. E., Berntsen, T., Berglen, T. F., Boucher, O., Chin, M., Collins, W., Dentener, F., Diehl, T., Easter, R., Feichter, J., Fillmore, D., Ghan, S., Ginoux, P., Gong, S., Grini, A., Hendricks, J., Herzog, M., Horowitz, L., Isaksen, I., Iversen, T., Kirkevåg, A., Kloster, S., Koch, D., Kristjansson, J. E., Krol, M., Lauer, A., Lamarque, J. F., Lesins, G., Liu, X., Lohmann, U., Montanaro, V., Myhre, G., Penner, J., Pitari, G., Reddy, S., Seland, O., Stier, P., Takemura, T., and Tie, X.: An AeroCom initial assessment - optical 
properties in aerosol component modules of global models, Atmos. Chem. Phys., 6, 1815-1834, doi:10.5194/acp-6-1815-2006, 2006.

Lohmann, U., Rotstayn, L., Storelvmo, T., Jones, A., Menon, S., Quaas, J., Ekman, A. M. L., Koch, D., and Ruedy, R.: Total aerosol effect: radiative forcing or radiative flux perturbation?, Atmos. Chem. Phys., 10, 3235-3246, doi:10.5194/acp-10-32352010, 2010.

Levy, R. C., Remer, L. A., Kleidman, R. G., Mattoo, S., Ichoku, C., Kahn, R., and Eck, T. F.: Global evaluation of the Collection 5 MODIS dark-target aerosol products over land, Atmos. Chem. Phys., 10, 10399-10420, doi:10.5194/acp-10-10399-2010, 2010.

Longo, K. M., Freitas, S. R., Dias, M. A. S., and Dias, P. L. S.: Numerical modelling of the biomass-burning aerosol direct radiative effects on the thermodynamics structure of the atmosphere and convective precipitation, in: International Conference on Southern Hemisphere Meteorology and Oceanography (ICSHMO), 8, Foz do Iguaçu, Proceedings, 283-289, 2006.

Longo, K. M., Freitas, S. R., Andreae, M. O., Yokelson, R., and Artaxo, P.: Biomass burning in Amazonia: Emissions, long-range transport of smoke and its regional and remote impacts, in: Amazonia and Global Change, Geophys. Monogr. Ser., AGU, Washington, DC, 207-232, 2009.

Longo, K. M., Freitas, S. R., Andreae, M. O., Setzer, A., Prins, E., and Artaxo, P.: The Coupled Aerosol and Tracer Transport model to the Brazilian developments on the Regional Atmospheric Modeling System (CATT-BRAMS) - Part 2: Model sensitivity to the biomass burning inventories, Atmos. Chem. Phys., 10, 5785-5795, doi:10.5194/acp-10-5785-2010, 2010.

Longo, K. M., Freitas, S. R., Pirre, M., Marécal, V., Rodrigues, L. F., Panetta, J., Alonso, M. F., Rosário, N. E., Moreira, D. S., Gácita, M. S., Arteta, J., Fonseca, R., Stockler, R., Katsurayama, D. M., Fazenda, A., and Bela, M.: The chemistry CATT-BRAMS model (CCATT-BRAMS 4.5): a regional atmospheric model system for integrated air quality and weather forecasting and research, Geosci. Model Dev. Discuss., 6, 1173-1222, doi:10.5194/gmdd6-1173-2013, 2013.

Menon, S.: Current uncertainties in assessing aerosol effects on climate, Annu. Rev. Env. Resour., 29, 1-30, doi:10.1146/annurev.energy.29.063003.132549, 2004.

O’Neill, N. T., Eck, T. F., Holben, B. N., Smirnov, A., Dubovik, O., and Royer, A.: Bimodal size distribution influences on the variation of Angstrom derivatives in spectral and optical depth space, J. Geophys. Res., 106, 9787-9806, doi:10.1029/2000JD900245, 2001

O’Neill, N. T., Eck, T. F., Smirnov, A., Holben, B. N., and Thulasiraman, S.: Spectral discrimination of coarse and fine mode optical depth, J. Geophys. Res., 108, 4559, doi:10.1029/2002JD002975, 2003.

Pantoja, N. V. and Brown, I. F.: Acurácia dos sensores AVHRR, GOES e MODIS na detecção de incêndios florestais e queimadas a partir de observações aéreas no estado do Acre (in Portuguese), Brazil, paper presented at the XIII Symposium of Remote Sensing, Florianópolis, Brazil, 21-26 April 2007, INPE, 4501-4508, 2007.

Prins, E., Feltz, J., Menzel, W., and Ward, D.: An overview of GOES-8 diurnal fire and smoke results for SCAR-B and 1995 fire season in South America, J. Geophys. Res., 103, 31821-31835, 1998.
Procopio, A. S., Remer, L. A., Artaxo, P., Kaufman, Y. J., and Holben, B. N.: Modeled spectral optical properties for smoke aerosols in Amazonia, Geophys. Res. Lett., 30, 2265, doi:10.1029/2003g1018063, 2003.

Procopio, A. S., Artaxo, P., Kaufman, Y. J., Remer, L. A., Schafer, J. S., and Holben, B. N.: Multiyear analysis of amazonian biomass burning smoke radiative forcing of climate, Geophys. Res. Lett., 31, L03108, doi:10.1029/2003g1018646, 2004.

Ramanathan, V., Crutzen, P. J., Kiehl, J. T., and Rosenfeld, D.: Aerosols, Climate, and the Hydrological Cycle, Science, 294, 2119-2124, doi:10.1126/science.1064034, 2001.

Reid, J. S., Ferek, R. J., Blake, D. R., Martins, J. V., Dunlap, M. R., and Liousse, C.: Physical, chemical, and optical properties of regional hazes dominated by smoke in Brazil, J. Geophys. Res., 103, 32059-32080, doi:10.1029/98jd00458, 1998.

Reid, J. S., Eck, T. F., Christopher, S. A., Koppmann, R., Dubovik, O., Eleuterio, D. P., Holben, B. N., Reid, E. A., and Zhang, J.: A review of biomass burning emissions part III: intensive optical properties of biomass burning particles, Atmos. Chem. Phys., 5, 827-849, doi:10.5194/acp-5-827-2005, 2005.

Ricchiazzi, P., Yang, S., Gautier, C., and Sowle, D.: SBDART: A Research and Teaching Software Tool for PlaneParallel Radiative Transfer in the Earth's Atmosphere, B Am. Meteorol. Soc., 79, 2101-2114, doi:10.1175/15200477(1998)079<2101:sarats $>2.0 . c 0 ; 2,1998$.

Rosário, N. M. E.: Variability of aerosol optical properties over South America and the impacts of direct radiative effect of aerosols from biomass burning, Ph.D. thesis, Institute of Astronomy, Geophysics and Atmospheric Sciences, University of São Paulo, São Paulo, 2011 (in Portuguese).

Rosário, N. E., Yamasoe, M. A., Brindley, H., Eck, T. F., and Schafer, J.: Downwelling solar irradiance in the biomass burning region of the southern Amazon: Dependence on aerosol intensive optical properties and role of water vapor, J. Geophys. Res., 116, D18304, doi:10.1029/2011jd015956, 2011.

Savijärvi, H., Arola, A., and Räisänen, P.: Short-wave optical properties of precipitating water clouds, Q. J. Roy. Meteor. Soc., 123, 883-899, doi:10.1002/qj.49712354005, 1997.

Schafer, J. S., Eck, T. F., Holben, B. N., Artaxo, P., Yamasoe, M. A., and Procopio, A. S.: Observed reductions of total solar irradiance by biomass-burning aerosols in the Brazilian Amazon and Zambian Savanna, Geophys. Res. Lett., 29, 1823, doi:10.1029/2001g1014309, 2002.

Schroeder, W., Morisette, J. T., Csiszar, I., Giglio, L., Morton, D., and Justice, C. O.: Characterizing Vegetation Fire Dynamics in Brazil through Multisatellite Data: Common Trends and Practical Issues, Earth Interact., 9, 1-26, doi:10.1175/ei120.1, 2005.

Schroeder, W., Prins, E., Giglio, L., Csiszar, I., Schmidt, C., Morisette, J., and Morton, D.: Validation of GOES and MODIS active fire detection products using ASTER and ETM+ data, Remote Sens. Environ., 112, 2711-2726, doi:10.1016/j.rse.2008.01.005, 2008.

Schulz, M., Textor, C., Kinne, S., Balkanski, Y., Bauer, S., Berntsen, T., Berglen, T., Boucher, O., Dentener, F., Guibert, S., Isaksen, I. S. A., Iversen, T., Koch, D., Kirkevåg, A., Liu, X., Montanaro, V., Myhre, G., Penner, J. E., Pitari, G., Reddy, S., Seland, $\varnothing$., Stier, P., and Takemura, T.: Radiative forcing by aerosols as derived from the AeroCom present-day and pre-industrial simulations, Atmos. Chem. Phys., 6, 5225-5246, doi:10.5194/acp-6- 
5225-2006, 2006.

Schulz, M., Chin, M., and Kinne, S.: The Aerosol Model Comparison Project, AeroCom, Phase II: Clearing Up Diversity, IGAC Newsletter, No 41, May 2009.

Sestini, M., Reimer, E., Valeriano, D., Alvalá, R., Mello, E., Chan, C., and Nobre, C.: Mapa de cobertura da terra da Amazônia legal para uso em modelos meteorológicos, Anais XI Simpósio Brasileiro de Sensoriamento Remoto, 2901-2906, 2003.

Setzer, A. and Pereira, M.: Amazonia biomass burnings in 1987 and an estimate of their tropospheric emissions, Ambio, 20, 19-22, 1991.

Stone, T. A., Schlesinger, P., Houghton, R. A., and Woodwell, G. M.: A Map of the Vegetation of South America based on Satellite Imagery, Photogramm. Eng. Rem. S., 60, 441-451, 1994.

Stone, R. S., Augustine, J. A., Dutton, E. G., O'Neill, N. T., and Saha, A.: Empirical determinations of the longwave and shortwave radiative forcing efficiencies of wildfire smoke, J. Geophys. Res., 116, D12207, doi:10.1029/2010jd015471, 2011.

Sun, Z. and Shine, K. P.: Studies of the radiative properties of ice and mixed-phase clouds, Q. J. Roy. Meteorol. Soc., 120, 111137, doi:10.1002/qj.49712051508, 1994.

Textor, C., Schulz, M., Guibert, S., Kinne, S., Balkanski, Y., Bauer, S., Berntsen, T., Berglen, T., Boucher, O., Chin, M., Dentener, F., Diehl, T., Feichter, J., Fillmore, D., Ginoux, P., Gong, S., Grini, A., Hendricks, J., Horowitz, L., Huang, P., Isaksen, I. S. A., Iversen, T., Kloster, S., Koch, D., Kirkevåg, A., Kristjansson, J. E., Krol, M., Lauer, A., Lamarque, J. F., Liu, X., Montanaro, V., Myhre, G., Penner, J. E., Pitari, G., Reddy, M. S., Seland, Ø., Stier, P., Takemura, T., and Tie, X.: The effect of harmonized emissions on aerosol properties in global models an AeroCom experiment, Atmos. Chem. Phys., 7, 4489-4501, doi:10.5194/acp-7-4489-2007, 2007.
Toon, O. B., McKay, C. P., Ackerman, T. P., and Santhanam, K.: Rapid Calculation of Radiative Heating Rates and Photodissociation Rates in Inhomogeneous Multiple Scattering Atmospheres, J. Geophys. Res., 94, 16287-16301, doi:10.1029/JD094iD13p16287, 1989.

Walko, R. L., Band, L. E., Baron, J., Kittel, T. G. F., Lammers, R., Lee, T. J., Ojima, D., Pielke, R. A., Taylor, C., Tague, C., Tremback, C. J., and Vidale, P. L.: Coupled Atmosphere-Biophysics-Hydrology Models for Environmental Modeling, J. Appl. Meteorol., 39, 931-944, doi:10.1175/15200450(2000)039<0931:cabhmf>2.0.co;2, 2000.

Wiscombe, W. J.: Improved Mie scattering algorithms, Appl. Optics, 19, 1505-1509, 1980.

Yamasoe, M. A., Kaufman, Y. J., Dubovik, O., Remer, L. A., Holben, B. N., and Artaxo, P.: Retrieval of the real part of the refractive index of smoke particles from Sun/sky measurements during SCAR-B, J. Geophys. Res., 103, 31893-31902, doi:10.1029/98jd01211, 1998. 